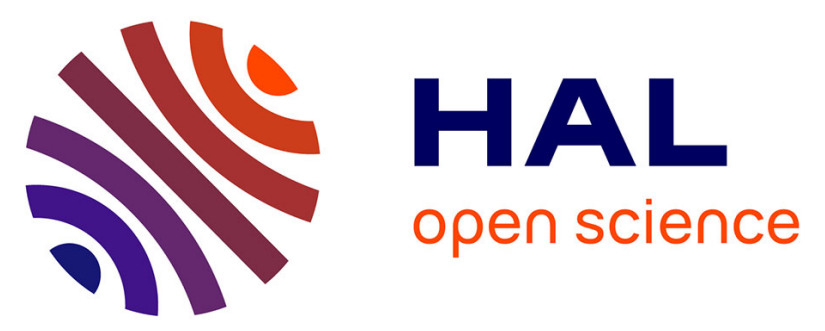

\title{
Glacial cold-water coral growth in the Gulf of Cádiz: Implications of increased palaeo-productivity
}

Claudia Wienberg, Norbert Frank, Kenneth Mertens, Jan-Berend Stuut, Margarita Marchant, Jan Fietzke, Furu Mienis, Dierk Hebbeln

\section{To cite this version:}

Claudia Wienberg, Norbert Frank, Kenneth Mertens, Jan-Berend Stuut, Margarita Marchant, et al.. Glacial cold-water coral growth in the Gulf of Cádiz: Implications of increased palaeo-productivity. Earth and Planetary Science Letters, 2010, 298 (3-4), pp.405-416. 10.1016/j.epsl.2010.08.017 . hal02890246

\section{HAL Id: hal-02890246 \\ https://hal.science/hal-02890246}

Submitted on 24 Jun 2021

HAL is a multi-disciplinary open access archive for the deposit and dissemination of scientific research documents, whether they are published or not. The documents may come from teaching and research institutions in France or abroad, or from public or private research centers.
L'archive ouverte pluridisciplinaire HAL, est destinée au dépôt et à la diffusion de documents scientifiques de niveau recherche, publiés ou non, émanant des établissements d'enseignement et de recherche français ou étrangers, des laboratoires publics ou privés. 


\section{Glacial cold-water coral growth in the Gulf of Cádiz: Implications of increased palaeo-productivity}

Claudia Wienberg ${ }^{\mathrm{a}, *}$, Norbert Frank $^{\mathrm{b}}$, Kenneth N. Mertens ${ }^{\mathrm{c}}$, Jan-Berend Stuut ${ }^{\mathrm{d}, \mathrm{a}}$, Margarita Marchant ${ }^{\mathrm{e}}$, Jan Fietzke ${ }^{\mathrm{f}}$, Furu Mienis ${ }^{\mathrm{a}, \mathrm{d}}$, Dierk Hebbeln ${ }^{\mathrm{a}}$

a Center for Marine Environmental Sciences (MARUM), University of Bremen, Leobener Str., 28359 Bremen, Germany

${ }^{b}$ Laboratoire des Sciences du Climat et de l'Environnement (LSCE), Bât.12, Avenue de la Terrasse, F-91198 Gifsur-Yvette, France

c Research Unit Palaeontology (RUP), Ghent University, Krijgslaan 281 S8, 9000 Ghent, Belgium

${ }^{d}$ Royal Netherlands Institute for Sea Research (NIOZ), Landsdiep 4, 1797 SZ t'Horntje (Texel), The Netherlands

e Departamento de Zoología, Facultad de Ciencias Naturales y Oceanográficas, Universidad de Concepción, Casilla 160-C, Concepción, Chile

${ }^{f}$ Leibniz-Institute of Marine Sciences, IFM-GEOMAR, Wischhofstr. 1-3, 24148 Kiel, Germany

* Corresponding author. Tel: +49 421 21865652; Fax: +49 4212189865652 E-mail address: cwberg@marum.de (C. Wienberg) 


\section{ABSTRACT}

2 A set of 40 Uranium-series datings obtained on the reef-forming scleractinian cold-water

3 corals Lophelia pertusa and Madrepora oculata revealed that during the past $400 \mathrm{kyr}$ their

4 occurrence in the Gulf of Cádiz (GoC) was almost exclusively restricted to glacial periods.

5 This result strengthens the outcomes of former studies that coral growth in the temperate

6 NE Atlantic encompassing the French, Iberian and Moroccan margins dominated during

7 glacial periods, whereas in the higher latitudes (Irish and Norwegian margins) extended

8 coral growth prevailed during interglacial periods. Thus it appears that the biogeographical

9 limits for sustained cold-water coral growth along the NE Atlantic margin are strongly

10 related to climate change. By focussing on the last glacial-interglacial cycle, this study shows

11 that palaeo-productivity was increased during the last glacial. This was likely driven by the

12 fertilisation effect of an increased input of aeolian dust and locally intensified upwelling.

13 After the Younger Dryas cold event, the input of aeolian dust and productivity significantly

14 decreased concurrent with an increase in water temperatures in the GoC. This primarily

15 resulted in reduced food availability and caused a widespread demise of the formerly

16 thriving coral ecosystems. Moreover, these climate induced changes most likely caused a

17 latitudinal shift of areas with optimum coral growth conditions towards the northern NE

18 Atlantic where more suitable environmental conditions established with the onset of the

19 Holocene.

21 Keywords: cold-water corals; last glacial; productivity; aeolian dust; Gulf of Cádiz; NE Atlantic

\section{1. Introduction}

24 Along the NE Atlantic margin cold-water corals occur in a belt that extends from northern

25 Norway (Barents Sea, $70^{\circ} \mathrm{N}$; Lindberg et al., 2007) down to NW Africa (off Mauritania, $16^{\circ} \mathrm{N}$;

26 Colman et al., 2005). These ecosystems vary strongly with respect to their appearance, 

margin. With a horizontal dimension of several hundred meters to kilometres they developed to the largest known living cold-water coral reefs worldwide (Fosså et al., 2005).

30 Along the Irish margin cold-water corals are associated with coral mounds that vary in height from a few metres up to $380 \mathrm{~m}$ being often densely covered by living coral colonies (Wheeler et al., 2007, and refs. therein). Further to the south, cold-water corals mainly occur as isolated colonies or accumulations of fossil corals in the Bay of Biscay (Reveillaud et al., 2008), on seamounts (Duineveld et al., 2004) and within canyons along the Iberian margin (Tyler et al., 2009), and on coral mounds along the NW African margin (Wienberg et al., 2009).

Along with the geographic distribution, a distinct stratigraphic pattern regarding the 39 development of cold-water coral ecosystems along the NE Atlantic margin has been 40 observed during the last glacial-interglacial cycle. Reefs of Holocene age on the Norwegian 41 shelf started to develop after the retreat of glaciers at the termination of the last glacial 42 (Freiwald et al., 2004). The Irish coral mounds seem to be restricted to interglacials with a very few exceptions (Dorschel et al., 2005; Eisele et al., 2008) and the latest reestablishment of cold-water coral ecosystems appears to have been started after the Younger Dryas (YD) cold reversal (Frank et al., 2009). To the south along the French, Iberian and Moroccan margins, corals are suggested to have been widely distributed during the last

47 glacial (Schröder-Ritzrau et al., 2005; Wienberg et al., 2009). In actual fact, although the Gulf of Cádiz $(\mathrm{GoC})$ was recently identified to be an important cold-water coral site in the

49 temperate NE Atlantic, this area is at present mainly characterised by so-called 'coral 50 graveyards' with only very few living corals (Foubert et al., 2008; Wienberg et al., 2009).

51 Such current depauperation of live coral ecosystems might be explained by the recent 52 warm and oligotrophic conditions in the GoC forcing reduced food availability (Wienberg et 53 al., 2009). In addition, tidal currents and internal waves that have been identified to be 
54 important hydrodynamic processes for supplying food particles to and through the coral 55 thickets (White et al., 2005; White et al., 2007) nowadays do not seem to play a major role 56 in the GoC (Wienberg et al., 2009). However, the widespread occurrence of fossil corals

57 suggests more favourable oceanographic conditions in the past. Indeed, initial datings 58 revealed that cold-water corals have been common in the GoC during the last glacial 59 (Wienberg et al., 2009).

60

61 The present study aims to refine and extend this observed stratigraphic pattern of coral 62 occurrence along the NE Atlantic margin by 40 Uranium-series datings of reef-forming 63 scleractinian cold-water corals from sediment cores retrieved in various areas of the GoC. 64 Moreover, it is intended to relate the prosperity and/or demise of cold-water corals in the GoC

65 to a distinct environmental and oceanographic setting that altered along with climate change.

66 Thus, we aim to identify the main forcing factors triggering the development of cold-water coral 67 ecosystems in the GoC.

68

69 2. Regional setting

70 The GoC is situated west of the Strait of Gibraltar, and thus connects the open North Atlantic 71 Ocean and the Mediterranean Sea (Fig. 1). It is bordered by the Iberian Peninsula and the NW

72 African coasts and extends from Cape St. Vincent at the southwestern tip of Portugal down to 73 the Moroccan Atlantic margin at $33^{\circ} \mathrm{N}$ (Mauritzen et al., 2001). The lberian continental shelf 74 widens from $\sim 15 \mathrm{~km}$ west of Faro to $\sim 50 \mathrm{~km}$ further to the east (Garcia-Lafuente and Ruiz, 75 2007), which is similar to the width of the Moroccan shelf (<60 km; Mittelstaedt, 1991).

77 The deeper basin of the $\mathrm{GoC}$ is characterised by a widespread occurrence of diapiric ridges and mud volcanoes (Somoza et al., 2003). Many of these mud volcanoes were identified to be covered by fossil cold-water corals (Somoza et al., 2003; Wienberg et al., 2009). Further conspicuous topographic features in the GoC are hundreds of coral mounds that are 20-30 
$81 \mathrm{~m}$ in height, and $50-200 \mathrm{~m}$ in length, and that are covered by fossil corals. They are

82 restricted to the Moroccan margin where they have been found in a water depth between

83400 and 960 m (Foubert et al., 2008; Hebbeln et al., 2008; Wienberg et al., 2009). The coral mounds are mainly arranged as clusters and are situated amidst mud volcanoes and on top of diapiric ridges. Detailed knowledge about their origin, composition, and temporal development is to date still lacking.

Present-day oceanographic circulation in the GoC is dominated by the exchange of water masses between the Atlantic Ocean and the Mediterranean Sea (Ochoa and Bray, 1991). The relatively cold Atlantic Inflow Water flows eastward along the Iberian margin partly entering the Mediterranean Sea. It is composed of North Atlantic Surficial Water and North

92 Atlantic Central Water (NACW). The upper-thermocline NACW deepens from about $300 \mathrm{~m}$

93 water depth close to the Strait of Gibraltar to about $600 \mathrm{~m}$ in the outer and southern parts

94 of the gulf (Ochoa and Bray, 1991; Mauritzen et al., 2001). Below this level occurs

95 Mediterranean Outflow Water (MOW). Flowing westwards through the Strait of Gibraltar,

96 the MOW prevails in the northern gulf where it flows between $\sim 500$ and $1400 \mathrm{~m}$ water

97 depth above the North Atlantic Deep Water (NADW) (Ambar et al., 1999; Baringer and Price, 1999) and acts as a strong contour current (García et al., 2009). It is characterised by a permanent salinity maximum of $\sim 36-37$ and temperatures of 10.5 to $12^{\circ} \mathrm{C}$ (Fusco et al.,

100 2008). For the southern GoC along the Moroccan Atlantic margin information about its 101 hydrography is basically lacking (Machín et al., 2006). However, Pelegrí et al. (2005) suggests

102 the presence of MOW at $800 \mathrm{~m}$. This assumption is supported by the presence of an 103 anticyclone or meddy close to the Moroccan shelf which implies at least some temporary 104 southward transport of MOW along the Moroccan margin (Carton et al., 2002).

106 Today, the GoC constitutes an oligotrophic system with diminished primary production in 107 the surface waters (Behrenfeld et al., 2005). Cold and productive upwelling is restricted to a 
108 narrow band along the Portuguese coast (Garcia-Lafuente and Ruiz, 2007), and to the NW

109 African margin south of $31^{\circ} \mathrm{N}$ (Cape Ghir) (Mittelstaedt, 1991; Pelegrí et al., 2005). Due to a

110 prevailing anticyclonic circulation (Pelegrí et al., 2005), the basin of the GoC separates the

111 Iberian upwelling from the upwelling off NW Africa (Garcia-Lafuente and Ruiz, 2007).

112

\section{3. Material and methods}

\section{$114 \quad 3.1$ Core locations}

115 During three expeditions between 2003 and 2006, a set of ten coral-bearing sediment cores

116 was collected from various sites in the GoC (Table 1). The coring sites comprise two mud

117 volcanoes (Hespérides and Faro) along the Spanish margin and coral mounds along the

118 Moroccan margin which are situated on top of the prominent Renard Ridge and its

119 easternmost extension, the Pen Duick Escarpment. Finally, the southernmost core was

120 collected north of Meknes mud volcano (Fig. 1).

122 The sediment cores have a length between $2.2 \mathrm{~m}$ and $8.6 \mathrm{~m}$ and are made up of abundant

123 cold-water coral fragments embedded in a hemipelagic sediment matrix (Table 1). The

124 sediment cores collected from mud volcanoes along the Spanish margin only contain cold-

125 water corals in their upper parts, whereas the cores retrieved from coral mounds along the

126 Moroccan margin are characterised by the occurrence of coral fragments throughout the

127 sedimentary record.

129 To reconstruct oceanographic and environmental changes in the GoC during the last glacial-

130 interglacial cycle and to compare this with the temporal distribution pattern of cold-water

131 corals, sediment core GeoB $9064\left(35^{\circ} 24.91^{\prime} \mathrm{N}, 06^{\circ} 50.72^{\prime} \mathrm{W}, 702 \mathrm{~m}\right.$ water depth) was

132 selected for a multiproxy study (Fig. 1). Core GeoB 9064 was collected along the Moroccan 
133 margin (RV Sonne cruise SO175) and has a total length of $5.4 \mathrm{~m}$. Samples for the various

134 analyses were taken in 5-cm-intervals.

\section{$136 \quad 3.2 \mathrm{U} / \mathrm{Th}$ age determination on coral fragments}

137 Forty fragments of the reef-forming scleractinian coral species Madrepora oculata and

138 Lophelia pertusa were sampled at different core depths from the sediment cores listed in

139 Table 1. Uranium-series measurements were performed using multi-collector ICP and

140 thermo-ionization mass spectrometry at IFM-GEOMAR (Kiel, Germany; Fietzke et al., 2005)

141 and at LSCE (Gif-sur-Yvette, France; Frank et al., 2004; Douville et al., 2010). Prior to

142 analyses, samples were carefully cleaned to remove contaminants from the fossil skeleton

143 surfaces according to procedures described by Fietzke et al. (2005) and Frank et al. (2004).

144 Isotope concentrations and ratios as well as the absolute dates on the cold-water corals are

145 provided in Table 2. Whole procedure blank values of this sample set were measured to be

146 around $2 \mathrm{pg}$ for thorium (Th) and between 4 and $8 \mathrm{pg}$ for uranium (U). Both values are

147 negligible compared to U- and Th-concentrations of the studied corals. The reproducibility

148 of mass spectrometric measurements was tested using international $\mathrm{U}$ standard materials

149 such as HU1 and NBL112, which provided identical values as the ones published by Fietzke

150 et al. (2005) and Frank et al. (2004).

\section{$152 \quad 3.3$ Analyses on core GeoB 9064}

\section{$153 \quad$ 3.3.1 AMS radiocarbon dating}

154 Accelerator mass spectrometry (AMS) dating was performed at the Leibniz Laboratory for

155 Age Determinations and Isotope Research (University of Kiel, Germany; Nadeau et al.,

156 1997) and at the Poznań Radiocarbon Laboratory (Poznań, Poland). AMS ${ }^{14} \mathrm{C}$ dates were

157 determined on $8 \mathrm{mg}$ calcium carbonate of mixed planktonic foraminifera. All ages were

158 corrected for ${ }^{13} \mathrm{C}$ and a mean ocean reservoir age of 400 years (Bard, 1988). AMS ${ }^{14} \mathrm{C}$ ages 
159 were converted to calendar years using the CALPAL 2007 Hulu software (Joeris and

160 Weninger, 1998) and are reported as calendar years before present (ka; Table 3).

161

$162 \quad$ 3.3.2 Stable oxygen isotopes

163 The stable oxygen isotope $\left(\delta^{18} \mathrm{O}\right)$ composition of the planktonic foraminifera

164 Neogloboquadrina pachyderma (dex.) was measured with a Finnigan MAT 251 mass

165 spectrometer (Isotope Laboratory of the Department of Geosciences, University of Bremen,

166 Germany). The isotopic composition was measured on the $\mathrm{CO}_{2}$ gas evolved by treatment with

167 phosphoric acid at a constant temperature of $75^{\circ} \mathrm{C}$. A working standard (Burgbrohl $\mathrm{CO}_{2}$ gas)

168 was applied, which has been calibrated against PDB by using the NBS18, 19 and 20 standards.

169 Consequently, all $\delta^{18} \mathrm{O}$ data presented here are given relative to the PDB standard. Analytical

170 standard deviation was about $\pm 0.07 \%$.

171

\section{$172 \quad$ 3.3.3 Grain-size analysis and end-member modelling}

173 Grain sizes were measured on bulk and terrigenous material using a Malvern Instruments

174 Mastersizer 2000 (Hydraulic Research Laboratory, Borgerhout, Belgium), which determines

175 particle grain sizes between $0.26 \mu \mathrm{m}$ and $2046 \mu \mathrm{m}$ grouped into 66 size classes. The

176 terrigenous sediment fraction was obtained by treating bulk sediment with $\mathrm{H}_{2} \mathrm{O}_{2}(30 \%$ at

$\left.17785^{\circ} \mathrm{C}\right)$ and $\mathrm{HCl}\left(10 \%\right.$ at $\left.100^{\circ} \mathrm{C}\right)$ to remove organic carbon and calcium carbonate, respectively.

178 The sediments contained negligible amounts of biogenic opal, and microscopic analyses

179 revealed that the applied method successfully removed all biogenic constituents. Finally, the

180 samples were suspended in demineralised water by stirring and ultrasonic dispersion before

181 analysis.

182

183 The terrigenous fraction of deep-sea sediments in the ocean is considered a mixture of ice-

184 rafted, aeolian, and fluvial transported sediments. End-member modelling allows the 
185 distinction between possible lithic subpopulations of the grain-size spectrum (Weltje, 1997)

186 that can be assigned to different sediment transport mechanisms (e.g., Stuut et al., 2002;

187 Holz et al., 2007). To estimate the minimum number of end-members (EM) required for a

188 satisfactory approximation of the data, the coefficients of determination were calculated.

189 These coefficients represent the proportion of the variance of each grain-size class that can

190 be reproduced by the approximated data. This proportion is equal to the squared

191 correlation coefficient $\left(r^{2}\right)$ of input variables and their approximated values (Weltje, 1997;

192 Prins and Weltje, 1999). As the terrigenous sediment fraction from the southern GoC is

193 relatively fine-grained $(<170 \mu \mathrm{m})$, the number of input variables for the end-member model

194 of core GeoB 9064 was reduced from 66 to 47 classes in the range of $0.29-170 \mu \mathrm{m}$.

195

$196 \quad$ 3.3.4. Planktonic foraminiferal assemblage

197 The analysis for planktonic foraminiferal relative abundance counts is based on the

$198>150 \mu \mathrm{m}$ fraction. For each sample a minimum of $\sim 200$ specimens were identified following

199 the taxonomy of planktonic foraminifera proposed by Hemleben et al. (1989). For

200 Neogloboquadrina pachyderma the relative abundances of right (dex.) and left (sin.) coiling

201 individuals were determined, and the two forms were treated as individual species. The

202 data are represented as percentages of total planktonic foraminiferal number.

203

\section{4. Results}

205 4.1. U-series dating

206 All selected coral fragments indicated minor to moderate physico-chemical alteration or

207 dissolution which may disturb $U$-series ages. Initial $\delta^{234} U_{0}$ values are variable and range

208 between $125.9 \pm 2.7 \%$ o to $187.1 \pm 2.6 \%$ (Table 2, Fig. 2). Measured ${ }^{232}$ Th concentrations are

209 small $\left(<10 \mathrm{ng} \mathrm{g}^{-1}\right)$ for $75 \%$ of all samples (Fig. 2) but clearly specimens of Madrepora oculata

210 reveal more residual Th then Lophelia pertusa (Table 2). This is a consequence of the 
211 cleaning procedure as the thinner polyps and more fragile skeleton of $M$. oculata is by far

212 more difficult to clean. However, Th contamination is negligible since in general the

$213{ }^{230} \mathrm{Th} /{ }^{232} \mathrm{Th}$ activity ratios are $>1000$.

214

215 Calculated U-series ages from all investigated coral sites in the GoC range from 9.2 ka to

216 more than $400 \mathrm{ka}$ (Fig. 3). Two samples from core GeoB 12101 could not be dated due to

217 above equilibrium radioactive isotopic composition indicating U-series open system

218 behaviour. More than $90 \%$ of all obtained ages correspond to glacial periods (Marine

219 Isotope Stage (MIS) 2 back to MIS12), and 70\% of these glacial coral ages cluster within the

220 last glacial (MIS2-4) (Fig. 3). With regard to the initial $\delta^{234} U_{0}$, it is evident that the scatter

221 increases largely beyond a coral age of 150 ka which is clearly indicative of increasing U-

222 series system opening (Thompson et al., 2003; Scholz et al., 2004; Frank et al., 2006;

223 Robinson et al., 2006). Consequently, those ages are less precise than the measured

224 uncertainty would suggest which has to be taken in consideration for our data

225 interpretation. Corals ages between 14 and 60 ka yield a mean initial $\delta^{234} U_{0}$ of $143.2 \pm 2.3 \%$ o

226 ( $n=22,2 \sigma$ standard deviation), which is slightly lower than measured in modern corals and

227 seawater (146.6-149.6\%; Delanghe et al., 2002; Robinson et al., 2004). Thus either corals

228 suffer from minor $\mathrm{U}$-series system opening, and thus, preferential loss of ${ }^{234} \mathrm{U}$, or the glacial

229 mean value of seawater was slightly lower than compared to today as suggested by Esat et

230 al. (1999). Overall we consider that within a range of $149 \pm 10 \%$ calculated ages are

231 representing the chronological ages of the corals within the uncertainty of measurement

232 (see also Stirling et al., 1998; Robinson et al., 2004; Esat and Yokoyama, 2006). However,

233 we are aware that a more detailed analysis of the U-series data and uncertainties

234 considering potential seawater U-isotopic variations, diagenetic alteration and U-series

235 system opening is needed to improve in particular the quality of coral ages beyond $150 \mathrm{ka}$. 
238 The age model of core GeoB 9064 for the last $\sim 40 \mathrm{kyr}$ is based on six AMS ${ }^{14} \mathrm{C}$ age control 239 points and linear interpolation between these dates (Table 3, Fig. 4). The age model is 240 supported by the correlation of the $\delta^{18} \mathrm{O}$ measurements of the record (showing heavy $\delta^{18} \mathrm{O}$ 241 values of $1.5-2.5 \%$ or the last glacial and light values of $<1.0 \%$ or the Holocene; Fig. 4) 242 with the $\delta^{18} \mathrm{O}$ record of the GRIP ice core (GRIP Members, 1993). The estimated average 243 sedimentation rate is $\sim 16 \mathrm{~cm} \mathrm{ka}^{-1}$ (Table 3). Highest sedimentation rates of $18-24 \mathrm{~cm} \mathrm{ka}^{-1}$ occur 244 during MIS3 and the last deglaciation. Lowest sedimentation rates of 8-9 $\mathrm{cm} \mathrm{ka}^{-1}$ are obtained for 245 MIS2 and the Holocene (Fig. 4).

\subsection{Grain size distribution and source}

248 The median grain size of the terrigenous (bulk) fraction of sediment core GeoB 9064 varies 249 between $5.71 \mu \mathrm{m}(5.93 \mu \mathrm{m})$ and $12.03 \mu \mathrm{m}(17.88 \mu \mathrm{m})$. The last glacial period and the Younger 250 Dryas (YD) cold event are characterised by relatively coarse sediment deposition. In contrast, 251 during the Holocene a distinct and continuous decrease of grain sizes is clearly visible (6$2529 \mu \mathrm{m}$ ) (Fig. 4). A three-end-member model was created (with $r^{2}=0.77$ ) to describe the grain 253 size data set of core GeoB 9064. The grain size distributions of the three end members are all 254 unimodal, well-sorted and have relatively fine modal grain sizes with $25 \mu \mathrm{m}$ for EM1, $16 \mu \mathrm{m}$ 255 for EM2, and $5 \mu \mathrm{m}$ for EM3. Several sedimentological studies confirmed that aeolian 256 sediments deposited in the deep-sea close to the continent are coarser grained than 257 hemipelagic sediments with terrigenous sediments with mean grain sizes $>6 \mu \mathrm{m}$ being 258 generally attributed to aeolian transport, and sediments $<6 \mu \mathrm{m}$ to hemipelagic transport 259 (Ratmeyer et al., 1999; Prins et al., 2000). In addition, the mean modal sizes of present-day 260 aeolian dust, collected along a transect of the NW African coast $\left(33^{\circ} \mathrm{N}\right.$ to $\left.12^{\circ} \mathrm{S}\right)$ vary between $2618 \mu \mathrm{m}$ and $42 \mu \mathrm{m}$ (Stuut et al., 2005). Hence, for core GeoB 9064, the two coarsest end 262 members of the three-end-member model are considered to be of aeolian origin with EM1 
263 interpreted as 'coarse' aeolian dust and EM2 as 'fine' aeolian dust. In contrast, EM3 is

264 interpreted to result predominantly from fluvial input (Koopmann, 1981; Holz et al., 2007).

265 During the last glacial, the aeolian content varies considerably between $30 \%$ and $60 \%$ and 266 shows in particular during MIS3 rapid fluctuations. Close to the end of the last glacial ( 17 ka),

267 the aeolian content decreases before it increases again up to $60 \%$ during the YD. With the 268 end of the YD ( $\sim 11.5 \mathrm{ka})$, the proportion of the aeolian content on the total terrigenous 269 fraction decreases continuously down to $25 \%$ (Fig. 4).

270

271 The EM1/EM2-ratio is considered as a measure for the relative wind intensity (Stuut et al., 272 2002). For core GeoB 9064, relatively high wind strength is indicated for the last glacial 273 showing millennial-scale fluctuations. At $\sim 22 \mathrm{ka}$, the wind conditions changed dramatically. 274 Within a time period of $1.5 \mathrm{kyr}$, wind intensity decreased remarkably by $50 \%$ and stayed 275 low during the entire Holocene (Fig. 4). This is deduced from a reduction of the content of 276 'coarse' aeolian dust (EM1) to almost zero, whereas the 'fine' aeolian dust (EM2) slightly 277 increased towards the present.

279 4.4. Planktonic foraminiferal assemblage and abundance

280 The most abundant species in core GeoB 9064 is Neogloboquadrina pachyderma dex. 281 (27.1\%), followed by Globigerinita glutinata (21.1\%), Globigerina bulloides (15.8\%), and 282 Globorotalia inflata (12.2\%). Together with Globigerinoides ruber (5.2\%), Globorotalia 283 scitula (4.5\%), and N. pachyderma sin. (4.5\%), these species account on average for $>90 \%$ 284 of the total planktonic foraminifera.

286 Maximum relative abundances of $N$. pachyderma dex. is recorded during the last glacial, contributing up to $60 \%$ of the total planktonic foraminifera fauna. At the end of the last glacial

288 (15.5-14.5 ka), its relative abundances decreased remarkably down to $10 \%$, followed by an increase up to $40 \%$ during the YD. At the end of the YD ( $11.5 \mathrm{ka})$, relative abundances of $N$. 
290 pachyderma dex. significantly decreased down to $<5 \%$ (Fig. 5). A similar trend is indicated for

291 N. pachyderma sin., although it shows comparably lower abundances below $18 \%$. Another 292 abundant species during the last glacial was G. glutinata with relative abundances of $10-40 \%$.

293 During the course of the Holocene, its contribution was rather low with minimum rates of $294<10 \%$ except for the period between 10 and $8.5 \mathrm{ka}$, with relative abundances of up to $28 \%$. An opposite trend to the above mentioned species is observed for G. bulloides. Relatively low abundance occurred during the last glacial $(<20 \%)$, whereas during the Holocene, its relative contribution to the total fauna increased to $>20 \%$. In particular between 8.5 and $2 \mathrm{ka}, G$. bulloides was the most common species within the planktonic foraminiferal fauna with relative abundance of $30-48 \%$. Between 40 and $18 \mathrm{ka}$, abundances of $\mathrm{G}$. inflata were below

$30020 \%$, and increased up to $38 \%$ until the onset of the YD. During the Holocene, its abundances

301 varied between $8 \%$ and $20 \%$. One distinct minimum $(<10 \%)$ of $G$. inflata abundance is

302 indicated between 10 and 8.5 ka that mirrors the concomitant maxima of G. glutinata.

303 Contributions of G. scitula to the total fauna was rather moderate for most of the last glacial,

304 and decreased remarkably around $18 \mathrm{ka}$ to $<5 \%$, and remained low thereafter (Fig. 5). During

305 the last glacial and until the end of the YD ( 11.5 ka), G. ruber shows a low abundance of 0$30610 \%$ that increased to $10-25 \%$ during the Holocene. Globigerinoides sacculifer was even 307 absent during the last glacial. This species is exclusively found during the Holocene with 308 relative abundances of up to $7.5 \%$ (Fig. 5).

\section{5. Discussion}

\section{$311 \quad$ 5.1. Glacial coral growth phases in the Gulf of Cádiz}

312 During the past years, much effort has been invested into dating cold-water corals from 313 various sites along the NE Atlantic margin. The most comprehensive data set of coral ages 314 exists for the Irish margin and reveals that coral growth in this area is restricted to the 315 Holocene and prior interglacial periods (Frank et al., 2005; Rüggeberg et al., 2007; de Haas 
316 et al., 2009; Frank et al., 2009). In contrast, for coral sites south of $50^{\circ} \mathrm{N}$ the data set of coral

317 ages is rather scattered. However, the available dates suggest that the major phase of coral

318 growth along the French, Iberian and Moroccan margins coincide with the last glacial

319 period (Taviani et al., 1991; Schröder-Ritzrau et al., 2005; Wienberg et al., 2009).

321 For the GoC, it was shown that the reef-forming coral species Lophelia pertusa and Madrepora oculata have been restricted to a period between 12 and $45 \mathrm{ka}$ (Wienberg et al., 2009). This preliminary result is confirmed by our data. In addition, the U/Th dates presented here show that major phases of coral growth in the GoC are not solely restricted to the last glacial but also to prior glacial periods (back to MIS12), whereas during

326 interglacials coral growth seems to be reduced or even absent (Fig. 2).

328 Most conspicuous is that the widespread decline of the coral ecosystems in the GoC during 329 the YD cold reversal (12.9-11.5 ka) corresponds to the re-start of coral mound formation on

330 Rockall Bank and the re-establishment of coral mound growth along the slopes of the 331 Porcupine Seabight at around 11 ka (Frank et al., 2009). Regarding this pattern, we suggest 332 that at the transition of the last glacial-interglacial, a latitudinal shift of areas with optimum 333 cold-water coral growth conditions towards the northern NE Atlantic occurred that was most probably related to dramatic changes of the oceanographic and environmental conditions caused by climate change. Moreover, this northward shift happened rapidly over just a few hundreds of years and over a distance of $2000-2500 \mathrm{~km}$ (GoC to Irish margin).

338 Unfortunately, we still lack detailed understanding of the reproductive ecology and larval 339 dispersal mode of scleractinian cold-water corals. Histological studies show that the 340 cosmopolitan species L. pertusa exhibits an annual gametogenic cycle with spawning 341 around January/February (Waller and Tyler, 2005). The widespread occurrence of L. pertusa 342 and the rapid colonisation of man-made structures such as oil rigs ( $25 \mathrm{~mm}$ year ${ }^{-1}$; Bell and 
343 Smith, 1999), point to a dispersive planula larva being capable to remain in the water

344 column for several weeks.

346 5.2. Driving factors for coral growth

347 A combination of environmental and oceanographic conditions is required to promote a 348 sustained development of cold-water coral ecosystems. Cold-water corals require (1) hard 349 substrate to settle on, (2) protection against burial to grow, and (3) sufficient food supply.

350 Therefore, they predominate in areas where strong currents prevail that reduce deposition

351 of fine-grained sediments and supply large quantities of food (Roberts et al., 2006). Today,

352 thriving coral ecosystems occur in high concentrations in areas that are characterised by

353 enhanced primary production in the surface waters of eutrophic systems, allowing a

354 considerable part of the new production to be transported to the seafloor. In addition, tidal

355 currents and internal waves have been identified (1) to enhance concentrations of organic

356 matter at the shelf edge and (2) to transport fresh food particles to and through the cold-

357 water coral reefs (Frederiksen et al., 1992; White et al., 2005; White et al., 2007). Recently,

358 Dullo et al. (2008) indicated for the Celtic and Nordic margins that living cold-water corals

359 occur within the density envelope of sigma-theta $\left(\sigma_{\ominus}\right)=27.35-27.65 \mathrm{~kg} \mathrm{~m}^{-3}$ emphasising the

360 importance of physical boundary conditions. Finally, the world's most common cold-water

361 coral species Lophelia pertusa tends to be associated with oceanic water masses with a

362 temperature of $4-12^{\circ} \mathrm{C}$ (Roberts et al., 2006), and even up to $14^{\circ} \mathrm{C}$ in the Mediterranean Sea

363 (Taviani et al., 2005; Freiwald et al., 2009), salinities between 31.7 and 38.78 (Freiwald et

364 al., 2004; Davies et al., 2008), and oxygen concentrations of 4.3-7.2 $\mathrm{ml}^{-1}$ (for the NE

365 Atlantic; Davies et al., 2008).

367 For the GoC, all these requirements must have been fulfilled during glacial periods as coldwater corals were widespread during these times. During interglacial periods, these optimal environmental and oceanographic conditions must have been changed dramatically 
370 resulting in a widespread (gulf-wide) demise of the formerly thriving corals. As our obtained

371 coral ages mainly cluster within the last glacial ( 70\%), the environmental and

372 oceanographic changes of the GoC, focussing on the last glacial-interglacial cycle, are

373 discussed in detail to identify the main forcing factors for coral growth in the GoC.

\subsubsection{Effects of increased palaeo-productivity on cold-water coral growth}

376 Strong vertical fluxes of labile organic matter, as often found in eutrophic regions, result in

377 rich benthic fauna (e.g., De Stigter et al., 1998; Schmiedl et al., 2000; Fontanier et al., 2002).

378 In the NE Atlantic, seasonal algae blooms that sink rapidly to the deep-sea floor can even

379 have a positive effect on the reproductive biology of benthic invertebrates (Billett et al., 380 1983; Thiel et al., 1989; Tyler et al., 1992), a relationship which is also hypothesised for 381 Lophelia pertusa and Madrepora oculata thriving along the Irish margin (Waller and Tyler, 382 2005). Thus, enhanced productivity is a pre-requisite for a sustained development of 383 healthy cold-water coral ecosystems. Indeed, regions with enhanced primary production as

384 deduced from satellite-based observations of the chlorophyll content in surface waters 385 (Behrenfeld et al., 2005) seem to mirror the recent distribution of thriving coral sites in the 386 NE Atlantic.

388 Certain species of planktonic foraminifera strongly depend on primary productivity in the 389 modern ocean (Hemleben et al., 1989), and hence downcore variations of the abundance of 390 planktonic foraminiferal species within sedimentary records can be applied to assess 391 palaeo-productivity conditions (e.g., Ivanova et al., 2003). In this context, the 392 environmental constraints of the most abundant foraminiferal species identified for the 393 GoC are reviewed in detail. prefers relatively cold and nutrient-rich waters (e.g., Ganssen and Kroon, 2000; Chapman, 
398 margins that are characterised by pronounced seasonal upwelling, and thus, by high 399 phytoplankton density and prey abundance (Salgueiro et al., 2008; Wilke et al., 2009). The 400 opportunistic and cosmopolitan species Globigerinita glutinata is also strongly associated 401 with the increase in productivity during spring bloom events in the North Atlantic 402 (Chapman, 2010). However, the distribution of this species is found to be even more 403 significantly associated with productivity than that of $G$. bulloides, which can be explained 404 by its diet that preferentially consists of diatoms (Bé and Tolderlund, 1971; Hemleben et al., 405 1989; Schiebel et al., 2001). The sub-polar species Neogloboquadrina pachyderma dex. 406 prefers colder waters than G. bulloides (Bé and Tolderlund, 1971). Off the northern Iberian 407 margin, high percentages of this species have been related to increased productivity 408 generated by high river runoff (Salgueiro et al., 2008). In the GoC, G. glutinata and 409 N. pachyderma dex. clearly dominate the foraminiferal assemblage during the last glacial 410 with relative abundances of 55 to $75 \%$ (Fig. 5), thus pointing to rather nutrient-rich and cold 411 conditions compared to the following Holocene when both species account for only 10\%.

412 However, although G. bulloides is regarded as an indicator for nutrient enriched conditions 413 it shows an opposite trend compared to the other two species.

415 Globorotalia inflata is considered a non-upwelling species and high relative abundances of 416 this species in the North Atlantic coincide with oligotrophic waters (Pflaumann et al., 2003; 417 Salgueiro et al., 2008). The two surface-dwelling species Globigerinoides ruber and 418 Globigerinoides sacculifer show a preference towards oligotrophic conditions as well (e.g., 419 Ivanova et al., 2003; Mohtadi et al., 2007). These species prefer warm and well stratified 420 surface waters (Duplessy et al., 1981; Stoll et al., 2007; Chapman, 2010). For the NE 421 Atlantic, a significant increase in the relative abundances of $G$. sacculifer is observed when 422 surface stratification is at a maximum and high sea surface temperatures prevail (Chapman, 423 2010). The significant increase of G. ruber and G. sacculifer after the YD cold event as found in 

the Holocene.

427 Taking all these findings for the NE Atlantic into account, G. sacculifer, G. ruber and G. 428 inflata are inferred to represent a low-productivity assemblage, whereas G. glutinata, 429 G. bulloides and N. pachyderma dex. are grouped as indicators for enhanced productivity. 430 Similar to the approach of Stoll et al. (2007), we calculated the ratio of both assemblages 431 and interpreted this ratio as an indicator of productivity (Fig. 4f), regardless of their affinity to upwelling processes. This ratio clearly shows that during the last glacial palaeoproductivity was overall enhanced in the GoC, which is in particular expressed by high relative abundances of G. glutinata (Fig. 5). Following the end of the last glacial, this ratio significantly changed towards more oligotrophic conditions (Fig. 4).

\subsubsection{Implications of frontal upwelling on glacial productivity in the GoC}

This pattern of eutrophic conditions during the last glacial and oligotrophic conditions during the Holocene found for the GoC might be explained by a shift of the Azores Front (Rogerson et al., 2004). The Azores Front marks a zone of strong hydrographic transition associated with enhanced biological production caused by locally intense upwelling (Alves and DeVerdière, 1999). Today, the easternmost extension of the Azores Front is situated at $30^{\circ} \mathrm{N}$ off the Moroccan margin (Gould, 1985; Schiebel et al., 2002), and hence, does not

444 penetrate into the $\mathrm{GoC}$ that extends from $37^{\circ} \mathrm{N}$ to $33^{\circ} \mathrm{N}$ (Fig. 1). But there is evidence that 445 the Azores Front shifted northward and thus penetrated eastward into the GoC prior to 16 446 ka and during the YD (Rogerson et al., 2004). Rogerson et al. (2004) indicated this glacial 447 shift of the Azores Front towards the GoC by high abundances of the planktonic foraminifer 448 Globorotalia scitula in their records. This deep-dwelling species (100-700 m water depth) 449 (Schiebel et al., 2002) is used as an indicator for cool surface waters and enhanced vertical mixing at temperate latitudes (e.g., Thunell and Reynolds, 1984; Perez-Folgado et al., 2003). 
451 Today G. scitula is found in high numbers in the Azores Front where upwelling causes high

452 productivity (Schiebel et al., 2002), but it is almost absent in the GoC (Rogerson et al., 453 2004). The record of core GeoB 9064 shows that G. scitula is common prior to the Last 454 Glacial Maximum (LGM), but is rare throughout the Holocene (Fig. 5) pointing to enhanced productivity during the last glacial caused by frontal upwelling.

\subsubsection{Fertilisation effect of aeolian dust}

458 Besides the effect of locally intensified upwelling that likely occurred in the GoC during the 459 last glacial also the high input of aeolian dust might have significantly enhanced glacial 460 productivity in the area. Grain size data from various sediment cores in the GoC, including 461 our data (Fig. 4), show that during the last glacial mean grain sizes were rather coarse 462 compared to the following Holocene (e.g., Rogerson et al., 2005; Voelker et al., 2006). Up to now, these grain size variations have been primarily attributed to changes in the strength of

464 the prevailing bottom currents implying that bottom current strength was enhanced during the last glacial probably caused by a shift and intensification of the MOW's flow pathway (Schönfeld and Zahn, 2000; Rogerson et al., 2005; Voelker et al., 2006). Another common

467 finding for the GoC is a rather low Holocene sedimentation rate (e.g., Rogerson et al., 2005;

468 Voelker et al., 2006). Rogerson et al. (2005) estimated a Holocene accumulation rate that is 469 only one fifth of that of the last glacial, and thus is in agreement with our estimated rates 470 (Fig. 4). They assumed that this tremendous change in sedimentation rate was caused by a 471 higher sediment supply prior to the last deglaciation but without indicating the major 472 source of sediments supplied to the GoC.

474 However, this study shows that the variations in grain size and sedimentation rate as found 475 for the GoC are rather the result of changes in the source of the terrigenous sediments and 476 the amount of sediment input. Our grain size data clearly reveal that during the last glacial 477 the deposition of aeolian transported sediments prevailed in the GoC (Fig. 4). During this 
478 time rather arid and cold conditions prevailed over the NW African continent (Gasse, 2000),

479 and the intensity of the northern trade winds, which transport the aeolian dust, was

480 enhanced especially from about $36^{\circ} \mathrm{N}$ to $24^{\circ} \mathrm{N}$ (Sarnthein et al., 1981; Hooghiemstra et al.,

481 1987; Moreno et al., 2002). This is supported by our record showing that wind strength off

482 Morocco $\left(35^{\circ} \mathrm{N}\right)$ was significantly enhanced during the last glacial (Fig. 4). With the end of

483 the YD, the proportion of the aeolian content on the total terrigenous fraction decreased

484 continuously from 60 to $25 \%$ (Fig. 4), corresponding to the African humid period, which is

485 known to be characterised by a relatively humid and green Sahara with significantly lower

486 amounts of aeolian dust being produced (e.g., deMenocal et al., 2000; Gasse, 2000). The

487 African humid period terminated at $5.5 \mathrm{ka}$ and the area of the Saharan desert returned to a

488 state of hyperarid conditions (deMenocal et al., 2000). However, wind strength remained

489 relatively low compared to the strong glacial trade winds (Hooghiemstra et al., 1987) and

490 dust fluxes have been estimated to be today 2-4 times lower compared to the LGM

491 (Grousset et al., 1998). Also our data show no significant increase of the input of aeolian

492 dust in the GoC after 5.5 ka until today (Fig. 4).

493

494 The large input of aeolian dust during the last glacial coincides with a prosperous coldwater coral community in the GoC (Fig. 4). The link between dust input and coral prosperity was probably established by a simple fertilisation effect. During periods of enhanced Saharan dust input over the NE Atlantic, the supply of iron and manganese to the surface ocean is enhanced as well (de Jong et al., 2007) which promotes primary production in the surface waters (e.g., Boyd et al., 2000), and as a consequence, also might increase food

500 availability for the bathyal cold-water corals.

\section{$502 \quad$ 5.2.4 Limitation of water temperatures on the prosperity of cold-water corals}

503 The planktonic foraminiferal abundance data of core GeoB 9064 is consistent with the 504 thermal history of the LGM and deglaciation. The general warming of the North Atlantic at 
505 the transition from the last glacial to the Holocene is reflected by a considerable increase in

506 the abundance of $G$. ruber and G. sacculifer and a concurrent decrease in abundance of $N$.

507 pachyderma dex., which is even more pronounced after the YD cold reversal (Fig. 5). This

508 pattern is in agreement with other foraminiferal fauna records from the GoC (Sierro et al.,

509 1999; Rogerson et al., 2004). The change from rather cool towards warm surface waters

510 after the end of the YD was most likely accompanied by a change in subsurface

511 temperatures in intermediate water depths, thus having an impact on the bathyal cold-

512 water corals. Regarding the average temperatures of the intermediate water masses

513 prevailing in the GoC (NACW: $12^{\circ} \mathrm{C}$, Ait-Ameur and Goyet, 2006; MOW: $10.5-12^{\circ} \mathrm{C}$, Fusco et

514 al., 2008), it becomes obvious that at least today water temperatures are at the very upper

515 tolerance for reef-forming scleractinian cold-water corals such as Lophelia pertusa $\left(12^{\circ} \mathrm{C}\right.$;

516 Roberts et al., 2006). Moreover, dendrophylliid coral species that prefer rather warm

517 conditions compared to L. pertusa seem to have been more common during the late

518 Holocene (Wienberg et al., 2009).

\section{6. Conclusion}

521 This study clearly shows that the occurrence of cold-water corals in the GoC is dominant

522 within the last glacial and prior glacial periods and that hardly any cold-water corals exist in

523 this region during interglacials. Moreover, it could be identified that at the end of the YD

524 cold event a shift from eutrophic to oligotrophic and warm conditions have been

525 responsible for the demise of the formerly thriving coral ecosystems. The enhanced

526 productivity conditions during the last glacial have been most probably caused by (1) an

527 enhanced input of aeolian dust and (2) a shift of the Azores Fronts towards the GoC causing

528 locally intense upwelling. Both factor supported enhanced primary productivity in the GoC,

529 and thus resulted in enhanced food availability for the corals. By comparing our data set for

530 the GoC with coral ages from the Norwegian and Irish margins that reveal a sustained

531 prosperity of coral ecosystems right after the YD, it appears that a northward shift of areas 
532 with optimum cold-water coral growth conditions took place during the transition from the

533 last glacial to the recent interglacial. The cold-water corals responded very rapidly to

534 climate change over just a few hundreds of years, and it is most likely that in the course of

535 global warming going along with dramatic changes in the environmental setting this

536 northward trend will further continue.

537

538 Acknowledgements

539 The research leading to these results (U/Th and radiocarbon dates) has received funding from the European

540 Community's Seventh Framework Programme (FP7/2007-2013) under the HERMIONE project, grant agreement

$541 n^{\circ}$ 226354. In addition, this work is part of CARBONATE (palaeo-environmental reconstructions), an ESF

542 EUROCORES integrated project as part of the EurOMARC project cluster funded by the DFG. K.M. Mertens is a

543 Postdoctoral Researcher funded by the FWO. M. Marchant acknowledges the Dirección de Investigación and

544 Departamento de Zoología at the University of Concepción (Chile) and the German Academic Exchange Service

545 (DAAD). On-board assistance by ship and scientific team during cruises SO175 with RV Sonne (2003), 64PE229

546 with RV Pelagia (2004) and MSM01-3 with RV Maria S. Merian (2006) is acknowledged. O. Pfannkuche, J.

547 Schönfeld and L. Maignien are kindly thanked for their great scientific support during cruise MSM01-3. We

548 further acknowledge the support of the staff of the LSCE Gif-sur-Yvette (E. Douville, E. Sallé, C. Noury), the

549 German Leibniz Laboratory for Age Determination and Isotope Research (University of Kiel, Germany), and the

550 Poznan Radiocarbon Laboratory (Poznan, Poland) in U/Th and radiocarbon dating as well as the staff of the UGhent (M. Verreth, A. Raes, F. Mostaert) in sample preparation and grain size analysis. Finally, A. Eisenhauer, M. Mohtadi and two anonymous reviewers are kindly thanked for helpful discussions and comments.

\section{References}

Ait-Ameur, N., Goyet, C., 2006. Distribution and transport of natural and anthropogenic $\mathrm{CO}_{2}$ in the Gulf of Cádiz. Deep-Sea Res. II 53, 1329-1343.

Alves, M., DeVerdière, A.C., 1999. Instability dynamics of a subtropical jet and applications to the Azores Front current system: Eddydriven mean flow. J. Physic. Oceanogr. 29, 837-864.

Ambar, I., Armi, L., Bower, A., Ferreira, T., 1999. Some aspects of time variability of the Mediterranean outflow. Deep-Sea Res. 26A, 1109-1136.

Bard, E., 1988. Correction of accelerator mass spectrometry ${ }^{14} \mathrm{C}$ ages measured in planktonic foraminifera: Paleoceanographic implications. Paleoceanography 3, 635-645.

Baringer, M.O., Price, J.F., 1999. A review of the physical oceanography of the Mediterranean outflow. Mar. Geol. 155, 63-82.

Bé, A.W.H., Tolderlund, D.S., 1971. Distribution and ecology of living planktonic foraminifera in surface waters of the Atlantic and Indian Oceans. In: Funel, B.M., Riedel, W.R. (Eds.), The Micropaleontology of Oceans. Cambridge University Press, pp. 105-149.

Behrenfeld, M.J., Boss, E., Siegel, D.A., Shea, D.M., 2005. Carbon-based ocean productivity and phytoplankton physiology from space. Glob. Biogeochem. Cycl. 19, GB1006, doi:1010.1029/2004GB002299.

Bell, N., Smith, J.E., 1999. Coral growing on North Sea oil rigs. Nature 402, 601.

Billett, D.S.M., Lampitt, R.S., Rice, A.L., Mantoura, R.F.C., 1983. Seasonal sedimentation of phytoplankton to the deep-sea benthos. Nature Geosci. 302, 520-522.

Boyd, P.W., Watson, A.J., Law, C.S., Abraham, E.R., Trull, T., Murdoch, R., Bakker, D.C.E., Bowie, A.R., Buesseler, K.O., Chang, H., Charette, M., Croot, P., Downing, K., Frew, R., Gall, M., Hadfield, M., Hall, J., Harvey, M., Jameson, G., LaRoche, J., Liddicoat, M., Ling, R., Maldonado, M.T., McKay, R., Nodder, S., Pickmere, S., Pridmore, R., Rintoul, S., Safi, K., Sutton, P., Strzepek, R., Tanneberger, K., Turner, S., Waite, A., Zeldis, J., 2000. 

407, 695-702.

Carton, X., Chérubin, L., Paillet, J., Morel, Y., Serpette, A., Le Cann, B., 2002. Meddy coupling with a deep cyclone in the Gulf of Cádiz. J. Mar. Syst. 32, 13-42.

Chapman, M.R., 2010. Seasonal production pattern of planktonic foraminifera in the NE Atlantic Ocean: Implications for paleotemperature and hydrographic reconstructions. Paleoceanography 25, PA1101, doi:10.1029/2008PA001708. Northwest Africa: status of deep-water corals and implications for management of fishing and oil exploration activities. In: Freiwald, A., Roberts, J.M. (Eds.), Cold-water Corals and Ecosystems. Springer, Heidelberg, pp. 417-441.

Davies, A.J., Wisshak, M., Orr, J.C., Roberts, J.M., 2008. Predicting suitable habitat for the cold-water coral Lophelia pertusa (Scleractinia). Deep-Sea Res. I 55, 1048-1062.

de Haas, H., Mienis, F., Frank, N., Richter, T.O., Steinbacher, R., de Stigter, H., van der Land, C., van Weering, T.C.E., 2009. Morphology and sedimentology of (clustered) cold-water coral mounds at the south Rockall Trough margins, NE Atlantic Ocean. Facies 55, 1-26.

de Jong, J.T.M., Boyé, M., Gelado-Caballero, M.D., Timmermans, K.R., Veldhuis, M.J.W., Nolting, R.F., van den Berg, C.M.G., de Baar, H.J.W., 2007. Inputs of iron, manganese and aluminium to surface waters of the Northeast Atlantic Ocean and the European continental shelf. Mar. Chem. 107, 120-142.

De Stigter, H.C., Jorissen, F.J., Vand der Zwaan, G.J., 1998. Bathymetric distribution and microhabitat partitioning of live (Rose Bengal stained) benthic foraminifera along a shelf to deep sea transect in the southern Adriatic Sea. J. Foram. Res. 28, 40-65.

Delanghe, D., Bard, E., Hamelin, B., 2002. New TIMS constraints on the uranium-238 and uranium-234 in seawaters from the main ocean basins and the Mediterranean Sea. Mar. Chem. 80, 79-93.

deMenocal, P., Ortiz, J., Guilderson, T., Adkins, J., Sarnthein, M., Baker, L., Yarusinsky, M., 2000. Abrupt onset and termination of the African Humid Period:: rapid climate responses to gradual insolation forcing. Quat. Sci. Rev. 19, 347-361.

Dorschel, B., Hebbeln, D., Rüggeberg, A., Dullo, W.-C., 2005. Growth and erosion of a cold-water coral covered carbonate mound in the Northeast Atlantic during the Late Pleistocene and Holocene. Earth Planet. Sci. Lett. 233, 33-44.

Douville, E., Sallé, E., Frank, N., Eisele, M., Pons-Branchu, E., Ayrault, S., 2010. Rapid and accurate Th-U dating of ancient carbonates using Inductively Coupled Plasma-Quadrupole Mass Spectrometry. Chem. Geol. 272, 1-11. Duineveld, G.C.A., Lavleye, M.S.S., Berghuis, E.M., 2004. Particle flux and food supply to a seamount cold-water coral community (Galicia Bank, NW Spain). Mar. Ecol. Prog. Ser. 277, 13-23.

Dullo, C., Flögel, S., Rüggeberg, A., 2008. Cold-water coral growth in relation to the hydrography of the Celtic and Nordic European continental margin. Mar. Ecol. Prog. Ser. 371, 165-176.

Duplessy, J.C., Bé, A.W., Blanc, P.L., 1981. Oxygen and carbon isotopic composition and biogeographic distribution of planktonic foraminifera in the Indian Ocean. Palaeogeogr. Palaeoclimat. Palaeoecol. 33, 9-46. Eisele, M., Hebbeln, D., Wienberg, C., 2008. Growth history of a cold-water coral covered carbonate moundGalway Mound, Porcupine Seabight, NE-Atlantic. Mar. Geol. 253, 160-169.

Esat, T.M., McCulloch, M.T., Chappell, J., Pillans, B., Omura, A., 1999. Rapid fluctuations in sea level recorded at Huon Peninsula during the penultimate deglaciation. Science 283, 197-201.

Esat, T.M., Yokoyama, Y., 2006. Variability in the uranium isotopic composition of the oceans over glacialinterglacial timescales. Geochim. Cosmochim. Acta 70, 4140-4150.

Fietzke, J., Liebetrau, V., Eisenhauer, A., Dullo, W.-C., 2005. Determination of uranium isotope ratios by multistatic MIC-ICP-MS: method and implementation for precise $U$ - and Th-series isotopes. J. Anal. Atomic Spectrom. 20, 395-401.

Fontanier, C., Jorissen, F.J., Licari, L., Alexandre, A., Anshutz, P., Carbonel, P., 2002. Live benthic foraminiferal faunas from the Bay of Biscay: faunal density, composition, and microhabitats. Deep-Sea Res. I 49, 751-785. Fosså, J.H., Lindberg, B., Christensen, O., Lundälv, T., Svellingen, I., Mortensen, P.B., Alsvag, J., 2005. Mapping of Lophelia reefs in Norway: experiences and survey methods. In: Freiwald, A., Roberts, J.M. (Eds.), Cold-water Corals and Ecosystems. Springer, Heidelberg, pp. 359-391.

Foubert, A., Depreiter, D., Beck, T., Maignien, L., Pannemans, B., Frank, N., Blamart, D., Henriet, J.-P., 2008. Carbonate mounds in a mud volcano province off north-west Morocco: key to processes and controls. Mar. Geol. 248, 74-96.

Frank, N., Paterne, M., Ayliffe, L., van Weering, T.C.E., Henriet, J.-P., Blamart, D., 2004. Eastern North Atlantic deep-sea corals: tracing upper intermediate water $\Delta^{14} C$ during the Holocene. Earth Planet. Sci. Lett. 219, $297-$ 309.

Frank, N., Lutringer, A., Paterne, M., Blamart, D., Henriet, J.-P., van Rooij, D., van Weering, T.C.E., 2005. Deepwater corals of the northeastern Atlantic margin: carbonate mound evolution and upper intermediate water ventilation during the Holocene. In: Freiwald, A., Roberts, J.M. (Eds.), Cold-water Corals and Ecosystems.

638 Springer, Heidelberg, pp. 113-133. 
639

640

641

642

643

644

645

646

647

648

649

650

651

652

653

654

655

656

657

658

659

660

661

662

663

664

665

666

667

668

669

670

671

672

673

674

675

676

677

678

679

680

681

682

683

684

685

686

687

688

689

690

691

692

693

694

695

696

697

698

699

700

701

702
Frank, N., Turpin, L., Cabioch, G., Blamart, D., Tressens-Fedou, M., Colin, C., Jean-Baptiste, P., 2006. Open system $U$-series ages of corals from a subsiding reef in New Caledonia: Implications for sea level changes, and subsidence rate. Earth Planet. Sci. Lett. 249, 274-289.

Frank, N., Ricard, E., Lutringer-Paque, A., van der Land, C., Colin, C., Blamart, D., Foubert, A., Van Rooij, D., Henriet, J.-P., de Haas, H., van Weering, T.C.E., 2009. The Holocene occurrence of cold-water corals in the NE Atlantic: Implications for coral carbonate mound evolution. Mar. Geol. 266, 129-142.

Frederiksen, R., Jensen, A., Westerberg, H., 1992. The distribution of scleratinian coral Lophelia pertusa around the Faroe Islands and the relation to intertidal mixing. Sarsia 77, 157-171.

Freiwald, A., Fosså, J.H., Grehan, A., Koslow, T., Roberts, J.M., 2004. Cold-water Coral Reefs. UNEP-WCMC, Biodiversity Series 22, Cambridge, UK, p. 84.

Freiwald, A., Beuck, L., Rüggeberg, A., Taviani, M., Hebbeln, D., R/V Meteor Cruise M70-1 participants, 2009. The white coral community in the central Mediterranean Sea revealed by ROV surveys. Oceanography 22, 58-74.

Fusco, G., Artale, V., Cotroneo, Y., Sannino, G., 2008. Thermohaline variability of Mediterranean Water in the Gulf of Cádiz, 1948-1999. Deep-Sea Res. I 55, 1624-1638.

Ganssen, G., Kroon, D., 2000. The isotopic signature of planktonic foraminifera from the NE Atlantic surface sediments: implications for the reconstruction of past oceanic conditions. J. Geol. Soc. London 157, 693-699. Garcia-Lafuente, J., Ruiz, J., 2007. The Gulf of Cádiz pelagic ecosystem: A review. Prog. Oceanogr. 74, 228-251. García, M., Hernández-Molina, F.J., Llave, E., Stow, D.A.V., León, R., Fernández-Puga, M.C., Diaz del Río, V., Somoza, L., 2009. Contourite erosive features caused by the Mediterranean Outflow Water in the Gulf of Cádiz: Quaternary tectonics and oceanographic implications. Mar. Geol. 257, 24-40.

Gasse, F., 2000. Hydrological changes in the African tropics since the Last Glacial Maximum. Quat. Sci. Rev. 19, 189-211.

Gould, W.J., 1985. Physical oceanography of the Azores Front. Prog. Oceanogr. 14, 167-190.

GRIP Members, 1993. Climate instability during the last interglacial period recorded in the the GRIP ice core. Nature 364, 203-207.

Grousset, F.E., Parra, M., Bory, A., Martinez, P., Betrand, P., Shimmield, G., Ellam, R.M., 1998. Saharan wind regimes traced by the $\mathrm{Sr}-\mathrm{Nd}$ isotopic composition of subtropical Atlantic sediments: Last Glacial Maximum vs. today. Quat. Sci. Rev. 17, 395-409.

Hebbeln, D., Wienberg, C., cruise participants, 2008. Report and preliminary results of RV Pelagia cruise 64PE284, Cold-water corals in the Gulf of Cádiz and on Coral Patch Seamount, Portimao - Portimao, 18.02.09.03.2008. University of Bremen, Reports of the Department of Geosciences (GeoB) No. 265, p. 90.

Hemleben, C., Spindler, M., Anderson, O.R., 1989. Modern Planktonic Foraminifera. Springer, New York, 363 pp.

Holz, C., Stuut, J.B., Meggers, H., Rüdiger, H., 2007. Variability in terrigenous sedimentation processes off northwest Africa and its relation to climatic changes: inferences from grain-size distributions of a Holocene marine sediment record. Sediment. Geol. 202, 499-508.

Hooghiemstra, H., Bechler, A., Beug, H.-J., 1987. Isopollen maps for 18,000 years BP of the Atlantic offshore of Northwest Africa: Evidence for paleowind circulation. Paleoceanography 2, 561-582.

Imbrie, J., Hays, J.D., Martinson, D.G., McIntyre, A., Mix, A.C., Morley, J.J., Pisias, N.G., Prell, W.L., Shackleton, N.J., 1989. The orbital theory of Pleistocene climate: support from a revised chronology of the marine $\delta^{18} O$ record. In: Berger, A. (Ed.), Milankovitch and Climate. NATO ASI Series, Dordrecht, pp. 269-305.

Ivanova, E., Schiebel, R., Singh, A.D., Schmiedl, G., Niebler, H.-S., Hemleben, C., 2003. Primary production in the Arabian Sea during the last 135000 years. Palaeogeogr. Palaeoclimat. Palaeoecol. 197, 61-82.

Joeris, O., Weninger, B., 1998. Extension of the ${ }^{14} \mathrm{C}$ calibration curve to ca. 40,000 cal BC by synchronizing Greenland ${ }^{18} \mathrm{O} /{ }^{16} \mathrm{O}$ ice core records and North Atlantic foraminifera profiles: A comparison with U/Th coral data. Radiocarbon 40, 495-504.

Koopmann, B., 1981. Sedimentation von Saharastaub im subtropischen Nordatlantik während der letzten 25.000 Jahre. Meteor Forschungsergeb. 35, 23-59.

Lindberg, B., Berndt, C., Mienert, J., 2007. The Fugløy Reef at $70^{\circ} \mathrm{N}$; acoustic signature, geologic, geomorphologic and oceanographic setting. Int. J. Earth Sci. 96, 201-213.

Machín, F., Pelegrí, J.L., Marrero-Díaz, A., Laiz, I., Ratsimandresy, A.W., 2006. Near-surface circulation in the southern Gulf of Cádiz. Deep-Sea Res. II 53, 1161-1181.

Mauritzen, C., Morel, J., Paillet, J., 2001. On the influence of Mediterranean water on the central waters of the North Atlantic Ocean. Deep-Sea Res. 44, 1543-1574.

Mittelstaedt, E., 1991. The ocean boundary along the northwest African coast: Circulation and oceanographic properties at the sea surface. Prog. Oceanogr. 26, 307-355.

Mohtadi, M., Max, L., Hebbeln, D., Baumgart, A., Krück, N., Jennerjahn, T., 2007. Modern environmental conditions recorded in surface sediment samples off $W$ and SW Indonesia: Planktonic foraminifera and biogenic compounds analyses. Mar. Micropaleontol. 65, 96-112.

Moreno, A., Cacho, I., Canals, M., Prins, M.A., Sánchez-Goñi, M.-F., Grimalt, J.O., Weltje, G.J., 2002. Saharan dust transport and high-latitude glacial climatic variability: The Alboran Sea record. Quat. Res. 58, 318-328.

Nadeau, M.J., Schleicher, M., Grootes, P., Erlenkeuser, H., Gottolong, A., Mous, D.J.W., Sarnthein, M., Willkomm, N., 1997. The Leibniz-Labor AMS facility of the Christian-Albrechts University, Kiel, Germany. Nucl. Instrum. Methods Phys. Res. 123, 22-30.

Ochoa, J., Bray, N.A., 1991. Water mass exchange in the Gulf of Cádiz. Deep-Sea Res. 38 (S1), 5465-5503. 
Pelegrí, J.L., Marrero-Díaz, A., Ratsimandresy, A., Antoranz, A., Cisneros-Aguirre, J., Gordo, C., Grísolia, D., Hernández-Guerra, A., Láiz, I., Martínez, A., Parrilla, G., Pérez-Rodriguez, P., Rodríguez-Santana, A., Sangrà, P., 2005. Hydrographic cruises off northwest Africa: the Canary Current and the Cape Ghir region. J. Mar. Syst. 54, 39-63. Mediterranean planktonic foraminifera events and millennial climatic variability during the last 70 kyr. Mar. Micropaleontol. 48, 49-70.

Pflaumann, U., Sarnthein, M., Chapman, M., d'Abreu, L., Funnell, B., Huels, M., Kiefer, T., Maslin, M., Schulz, H., Swallow, J., van Kreveld, S., Vautravers, M., Vogelsang, E., Weinelt, M., 2003. Glacial North Atlantic: seasurface conditions reconstructed by GLAMAP 2000. Paleoceanography 18, 1065.

Prins, M.A., Weltje, G.J., 1999. End-member modeling of siliciclastic grain-size distributions: the Late Quaternary record of eolian and fluvial sediment supply to the Arabian Sea and its paleoclimatic significance. In: Harbaugh, J., Watney, L., Rankey, G., Slingerland, R., Goldstein, R., Franseen, E. (Eds.), Numerical Experiments in Stratigraphy: Recent Advances in Stratigraphic and Sedimentologic Computer Simulations. SEPM, pp. 91-111.

Prins, M.A., Postma, G., Cleveringa, J., Cramp, A., Kenyon, N.H., 2000. Controls on terrigenous sediment supply to the Arabian Sea during the late Quaternary: the Indus Fan. Mar. Geol. 169, 327-349.

Ratmeyer, V., Balzer, W., Bergametti, G., Chiapello, I., Fischer, G., Wyputta, U., 1999. Seasonal impact of mineral dust on deep-ocean particle flux in the eastern subtropical Atlantic Ocean. Mar. Geol. 159, 241-252.

Reveillaud, J., Freiwald, A., Van Rooij, D., Le Guilloux, E., Altuna, A., Foubert, A., Vanreusel, A., Olu-Le Roy, K., Henriet, J.-P., 2008. The distribution of scleractinian corals in the Bay of Biscay, NE Atlantic. Facies 54, 317-331. Roberts, J.M., Wheeler, A.J., Freiwald, A., 2006. Reefs of the deep: The biology and geology of cold-water coral ecosystems. Science 312, 543-547

Robinson, L.F., Belshaw, N.S., Henderson, G.M., 2004. $U$ and Th concentrations and isotope ratios in modern carbonates and waters from the Bahamas. Geochim. Cosmochim. Acta 68, 1777-1789.

Robinson, L.F., Adkins, J.F., Fernandez, D.P., Burnett, D.S., Wang, S.-L., Gagnon, A.C., Krakauer, N., 2006. Primary $U$ distribution in scleractinian corals and its implications for U series dating. Geochem. Geophysic. Geosyst. 7, Q05022, doi, 10.1029/2005GC001138.

Rogerson, M., Rohling, E.J., Weaver, P.P.E., Murray, J.W., 2004. The Azores Front since the Last Glacial Maximum. Earth Planet. Sci. Lett. 222, 779-789.

Rogerson, M., Rohling, E.J., Weaver, P.P.E., Murray, J.W., 2005. Glacial to interglacial changes in the settling depth of the Mediterranean Outflow plume. Paleoceanography 20, PA3007, doi:3010.1029/2004PA001106. Rüggeberg, A., Dullo, W.-C., Dorschel, B., Hebbeln, D., 2007. Environmental changes and growth history of a cold-water carbonate mound (Propeller Mound, Porcupine Seabight). Int. J. Earth Sci. 96, 57-72.

Salgueiro, E., Voelker, A., Abrantes, F., Meggers, H., Pflaumann, U., Loncaric, N., González-Álvarez, R., Oliveira, P., Bartels-Jónsdóttir, H.B., Moreno, J., Wefer, G., 2008. Planktonic foraminifera from modern sediments reflect upwelling patterns off Iberia: Insights from a regional transfer function. Mar. Micropaleontol. 66, 135-164.

Sarnthein, M., Tetzlaff, G., Koopmann, B., Wolter, K., Pflaumann, U., 1981. Glacial and interglacial wind regimes over the eastern tropical Atlantic and Northwest Africa. Nature 293, 193-196.

Schiebel, R., Waniek, J., Bork, M., Hemleben, C., 2001. Planktic foraminiferal production stimulated by chlorophyll redistribution and entrainment of nutrients. Deep-Sea Res. I 48, 721-740.

Schiebel, R., Waniek, J., Zeltner, A., Alves, M., 2002. Impact of the Azores Front on the distribution of planktic foraminifers, shelled gastropods and coccolithophorids. Deep-Sea Res. II 49, 4035-4050.

Schmiedl, G., de Bovée, F., Buscail, R., Charrière, B., Hemleben, C., Medernach, L., Picon, P., 2000. Trophic control of benthic foraminiferal abundance and microhabitat in the bathyal Gulf of Lions, western Mediterranean Sea. Mar. Micropaleontol. 40, 167-188.

Scholz, D., Mangini, A., Felis, T., 2004. U-series dating of diagenetically altered fossil reef corals. Earth Planet. Sci. Lett. 218, 163-178.

Schönfeld, J., Zahn, R., 2000. Late Glacial to Holocene history of the Mediterranean Outflow. Evidence from benthic foraminiferal assemblages and stable isotopes at the Portuguese margin. Palaeogeogr. Palaeoclimat. Palaeoecol. 159, 85-111.

Schröder-Ritzrau, A., Freiwald, A., Mangini, A., 2005. U/Th-dating of deep-water corals from the eastern North Atlantic and the western Mediterranean Sea. In: Freiwald, A., Roberts, J.M. (Eds.), Cold-water Corals and Ecosystems. Springer, Heidelberg, pp. 691-700.

Sierro, F.J., Flores, J.A., Baraza, J., 1999. Late glacial to recent paleoenvironmental changes in the Gulf of Cadiz and formation of sandy contourite layers. Mar. Geol. 155, 157-172.

Somoza, L., Diaz-del-Rio, V., Leon, R., Ivanov, M., Fernandez-Puga, M.C., Gardner, J.M., Hernandez-Molina, F.J., Pinheiro, L.M., Rodero, J., Lobato, A., 2003. Seabed morphology and hydrocarbon seepage in the Gulf of Cádiz mud volcano area: Acoustic imagery, multibeam and ultra-high resolution seismic data. Mar. Geol. 195, 153176.

Stirling, C.H., Esat, T.M., Lambeck, K., McCulloch, M.T., 1998. Timing and duration of the Last Interglacial: evidence for a restricted interval of widespread coral reef growth. Earth Planet. Sci. Lett. 160, 745-762.

Stoll, H.M., Arevalos, A., Burke, A., Ziveri, P., Mortyn, G., Shimizu, N., Unger, D., 2007. Seasonal cycles in biogenic production and export in Northern Bay of Bengal sediment traps. Deep-Sea Res. II 54, 558-580. 
Stuut, J.-B.W., Prins, M.A., Schneider, R.R., Weltje, G.J., Jansen, J.H.F., Postma, G., 2002. A 300-kyr record of aridity and wind strength in southwestern Africa: inferences from grain-size distributions of sediments on Walvis Ridge, SE Atlantic. Mar. Geol. 180, 221-233.

Stuut, J.B., Zabel, M., Ratmeyer, V.H., P., Schefuß, E., Lavik, G., Schneider, R.R., 2005. Provenance of present-day eolian dust collected off NW Africa: implications for deep-marine sediment studies. J. Geophys. Res. 110, D04202.

Taviani, M., Bouchet, P., Metivier, B., Fontugne, M., Delibrias, G., 1991. Intermediate steps of southwards faunal shifts testified by last glacial submerged thanatocoenoses in the Atlantic Ocean. Palaeogeography, Palaeoclimatology, Palaeocology 86, 331-338.

Taviani, M., Remia, A., Corselli, C., Freiwald, A., Malinverno, E., Mastrototaro, F., Savini, A., Tursi, A., 2005. First geo-marine survey of living cold-water Lophelia reefs in the lonian Sea (Mediterranean basin). Facies 50, 409417.

Thiel, H., Pfannkuche, O., Schriever, G., Lochte, K., Gooday, A.J., Hemleben, C., Mantoura, R.F.C., Turley, C.M., Patching, J.W., Riemann, F., 1989. Phytodetritus on the deep-sea floor in a central region of the Northeast Atlantic. Biol. Oceanogr. 6, 203-239.

Thompson, W.G., Spiegelman, M.W., Goldstein, S.L., Speed, R.C., 2003. An open-system model for U-series age determinations of fossil corals. Earth Planet. Sci. Lett. 210, 365-381.

Thunell, R., Reynolds, L., 1984. Sedimentation of planktonic foraminifera: Seasonal changes in species flux in the Panama Basin. Micropaleontology 30, 243-262.

Tyler, B., Amaro, T., Arzola, R., Cunha, M.R., De Stigter, H., Gooday, A., Huvenne, V., Ingels, J., Kiriakoulakis, K., Lastras, G., Masson, D.G., Oliveira, A., Pattenden, A., Vanreusel, A., Van Weering, T.C.E., Vitorino, J., Witte, U., Wolff, G., 2009. Europe's Grand Canyon: Nazaré Submarine Canyon. Oceanography 22, 46-57.

Tyler, P.A., Harvey, R., Giles, L.A., Gage, J.D., 1992. Reproductive strategies and diet in deep-sea nuculanid protobranchs (Bivalvia: Nuculoidea) from the Rockall Trough. Mar. Biol. 114, 571-580.

Voelker, A.H.L., Lebreiro, S.M., Schönfeld, J., Cacho, I., Erlenkeuser, H., Abrantes, F., 2006. Mediterranean outflow strengthening during northern hemisphere coolings: A salt source for the glacial Atlantic. Earth Planet. Sci. Lett. 245, 39-55.

Waller, R.G., Tyler, P.A., 2005. The reproductive biology of two deep-water, reef-building scleractinians from the NE Atlantic Ocean. Coral Reefs 24, 514-522.

Weltje, G., 1997. End-member modeling of compositional data: Numerical-statistical algorithms for solving the explicit mixing problem. Math. Geol. 29, 503-549.

Wheeler, A.J., Beyer, A., Freiwald, A., de Haas, H., Huvenne, V., Kozachenko, M., Olu-Le Roy, K., Opderbecke, J., 2007. Morphology and environment of cold-water coral carbonate mounds on the NW European margin. Int. J. Earth Sci. 96, 37-56.

White, M., Mohn, C., de Stigter, H., Mottram, G., 2005. Deep-water coral development as a function of hydrodynamics and surface productivity around the submarine banks of the Rockall Trough, NE Atlantic. In: Freiwald, A., Roberts, J.M. (Eds.), Cold-Water Corals and Ecosystems. Springer, Heidelberg, pp. 503-514. White, M., Roberts, J.M., van Weering, T.C.E., 2007. Do bottom-intensified diurnal tidal currents shape the alignment of carbonate mounds in the NE Atlantic? Geo-Mar. Lett. 27, 391-397.

Wienberg, C., Hebbeln, D., Fink, H.G., Mienis, F., Dorschel, B., Vertino, A., López Correa, M., Freiwald, A., 2009. Scleractinian cold-water corals in the Gulf of Cádiz - first clues about their spatial and temporal distribution. Deep-Sea Res. I 56, 1873-1893. in the Canary Islands region (29 $\mathrm{N}$ ) based on oxygen isotopes. Deep-Sea Res. I 56, 89-106. 
813 Figure 1. Map of the Gulf of Cádiz (GoC) showing the coring sites (bathymetric data source:

814 GEBCO). Reference sediment core GeoB 9064 (black triangle) and coral-bearing sediment

815 cores (A-D). A: Hespérides mud volcano (GeoB 9018), B: Faro mud volcano (GeoB 9031, GeoB

816 9032), C: Renard Ridge (GeoB 9070, GeoB 12101, GeoB 12102, GeoB 12103, GeoB 12104,

817 M2004-02), D: north of Meknes mud volcano (GeoB 12106). Indicated are the reported

818 occurrences of fossil cold-water corals (after Wienberg et al., 2009). Lower left: photographs

819 showing characteristic 'coral graveyards' in the southern GoC, Moroccan margin (position is

820 indicated on the map as p1, p2) (images @MARUM, Bremen).

821

822 Figure 2. Initial U-isotopic ratios of cold-water corals (lower graph) and ${ }^{232}$ Th concentration

823 (upper graph). $\delta^{234} \mathrm{U}$ is in almost all cases very close to present-day seawater (149.9\%o: blue

824 dashed line; range of $149.9 \pm 10 \%$ : light blue bar), except for the deepest sample in core GeoB

$82512104\left(+38 \%\right.$ o). ${ }^{232}$ Th concentrations for $75 \%$ of all samples are below $10 \mathrm{ng} \mathrm{g}^{-1}$ (green dashed

826 line).

827 Figure $3 .{ }^{230} \mathrm{Th} / \mathrm{U}$ datings conducted on cold-water coral fragments collected in the GoC.

828 AMS ${ }^{14} \mathrm{C}$ ages presented by Wienberg et al. (2009) are implemented. Note that solely reef-

829 forming species such as Madrepora oculata and Lophelia pertusa are considered showing

830 that $>90 \%$ of all coral ages coincide with glacial periods. Marine Isotope Stages (MIS) are

831 indicated by grey bars based on SPECMAP $\delta^{18}$ O stack (Imbrie et al. 1989).

832

833 Figure 4. Multi-proxy data of sediment core GeoB 9064. (a) Estimated sedimentation rate,

834 (b) stable oxygen isotopes record (lower curve) compared with the GRIP ice core record

835 (upper curve) (c) median grain size (terrigenous and bulk sediment), (d) relative aeolian

836 input, (e) relative wind strength, and (f) productivity index based on the ratio of high- to

837 low-productivity planktonic foraminiferal assemblages. AMS ${ }^{14} \mathrm{C}$ dates obtained for core

838 GeoB 9064 are marked by black diamonds. For comparison, U/Th (squares; this study) and

839 AMS ${ }^{14} \mathrm{C}$ coral dates (triangles; Wienberg et al., 2009) obtained for the past $50 \mathrm{kyr}$ are 
840 implemented. Note that solely reef-forming species such as Madrepora oculata and $841 \quad$ Lophelia pertusa are considered.

842

843 Figure 5. The $\delta^{18} \mathrm{O}$ record and planktonic foraminiferal abundance for sediment core GeoB

844 9064. (a) $\delta^{18} \mathrm{O}_{\text {N. pachyderma (dex.), }}$ (b) Neogloboquadrina pachyderma (black: dex., grey: sin.), (c)

845 Globigerinita glutinata, (d) Globigerina bulloides, (e) Globigerinoides ruber (black) and

846 Globigerinoides sacculifer (grey), (f) Globorotalia inflata, (g) Globorotalia scitula. Younger

847 Dryas (YD) and Marine Isotope Stages (MIS) 2 and 3 are indicated.

848

849 


\section{Figure 1}

Click here to download high resolution image

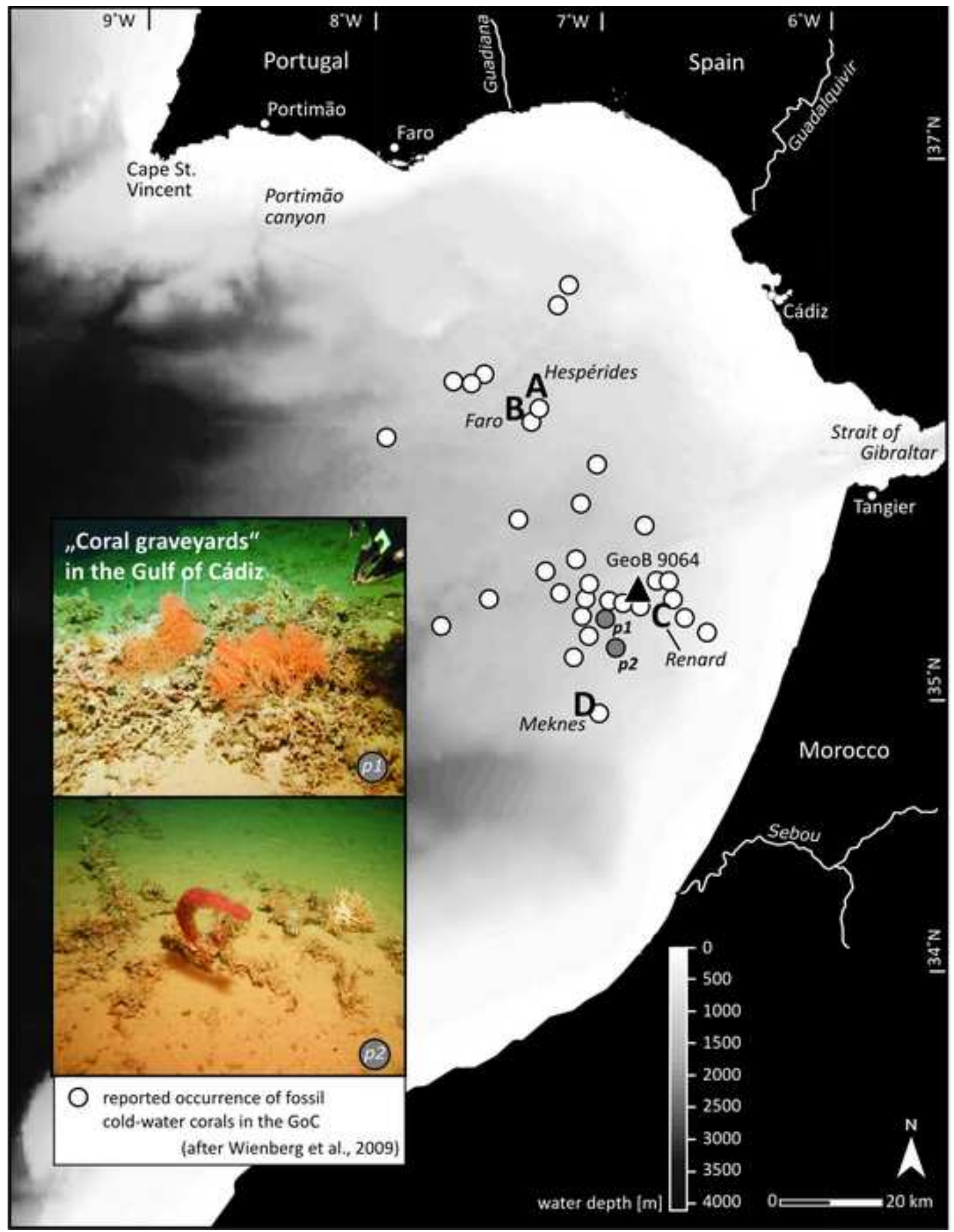


Click here to download high resolution image

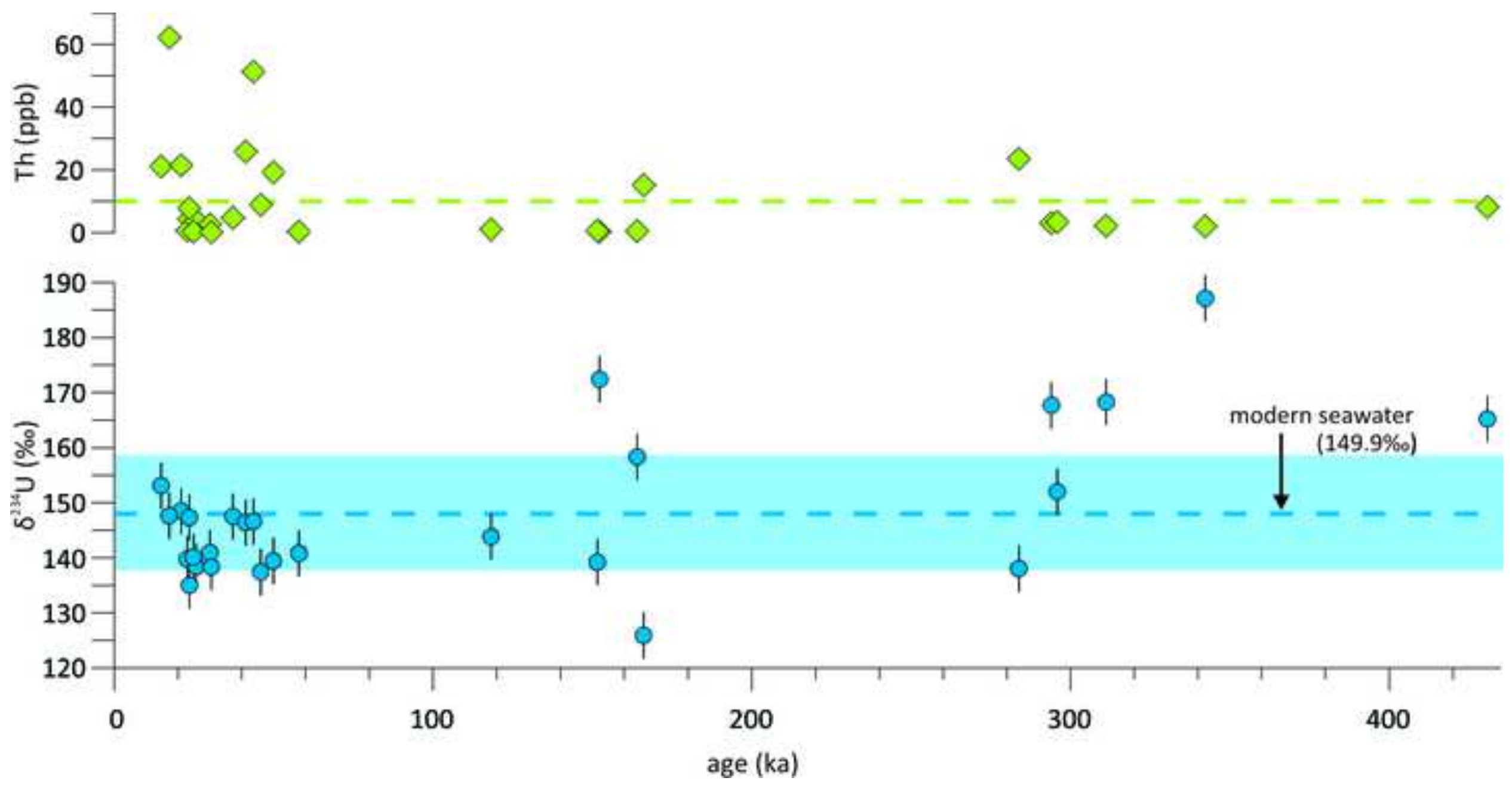


Click here to download high resolution image

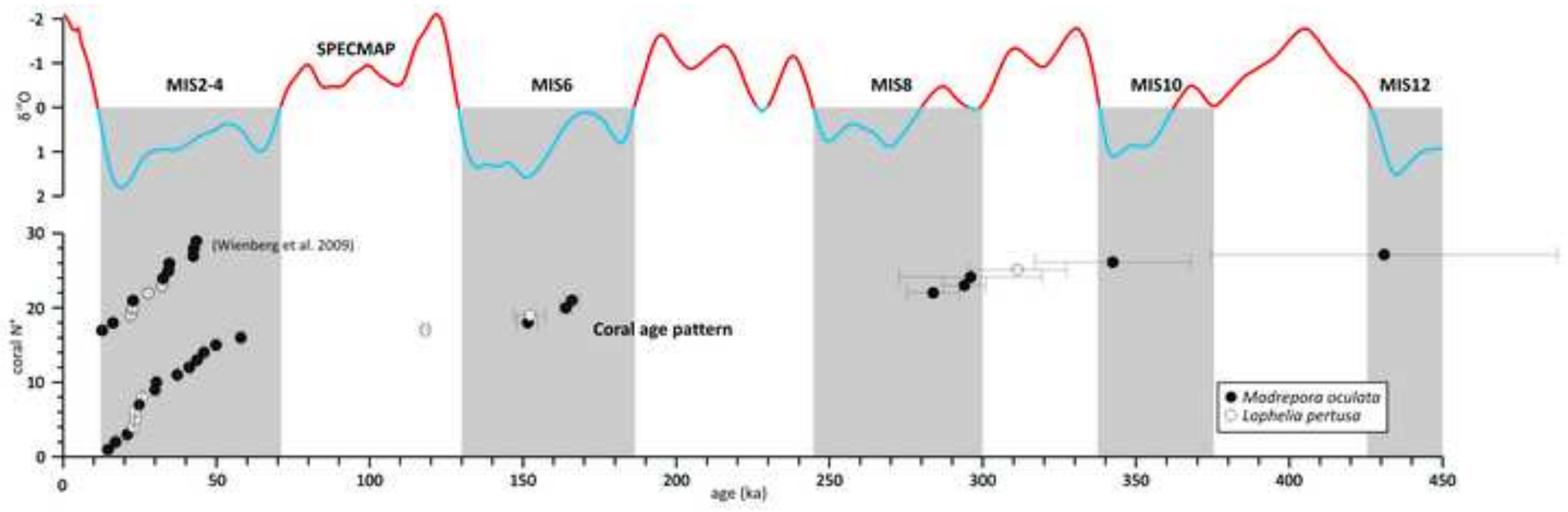




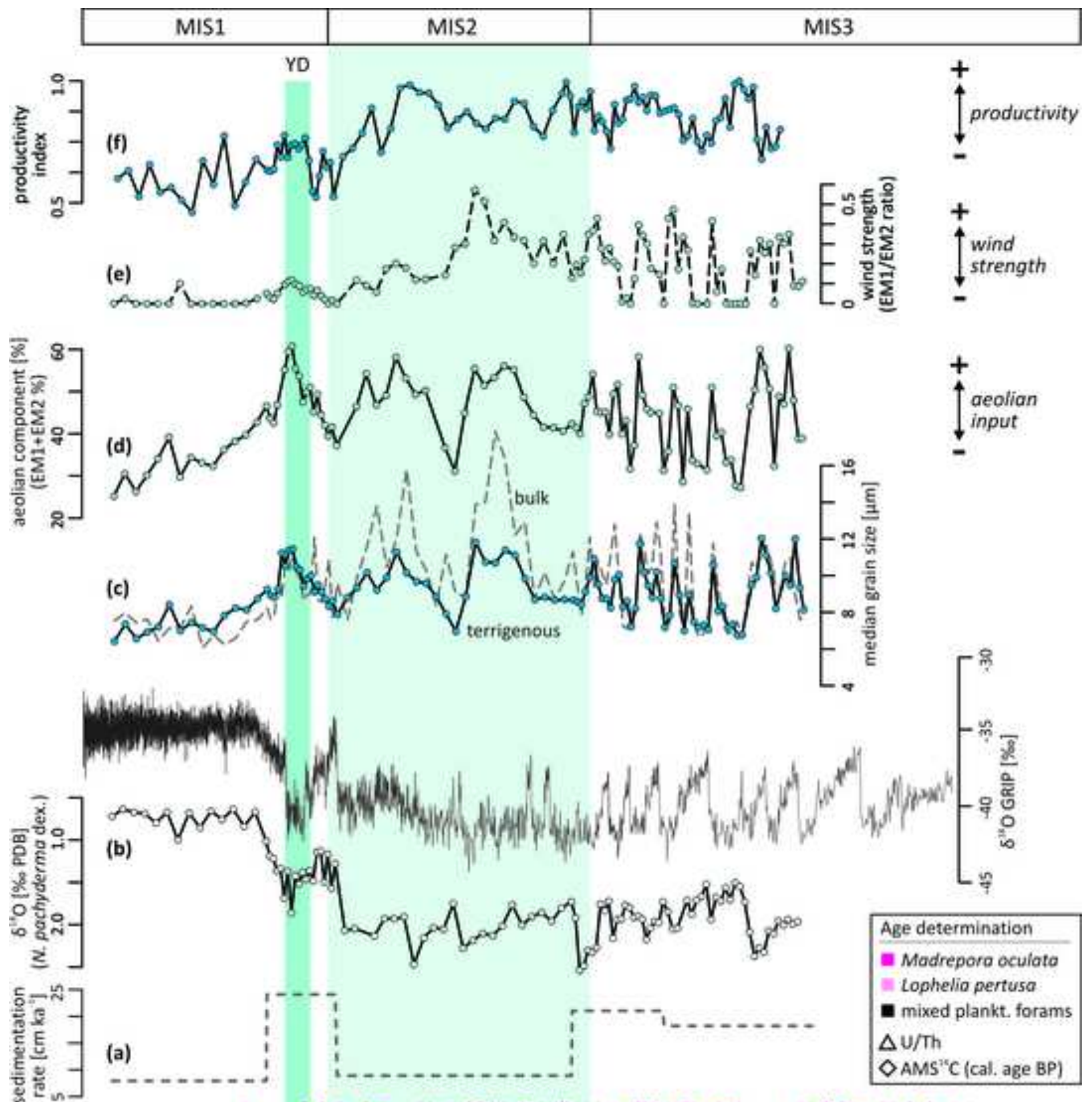

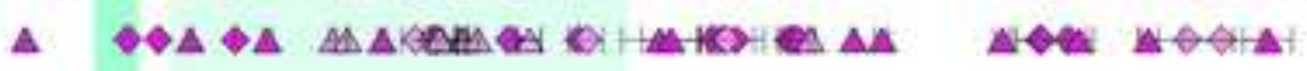

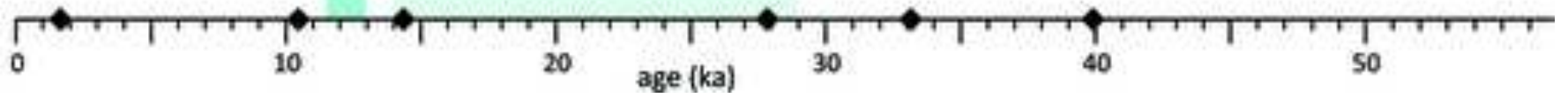




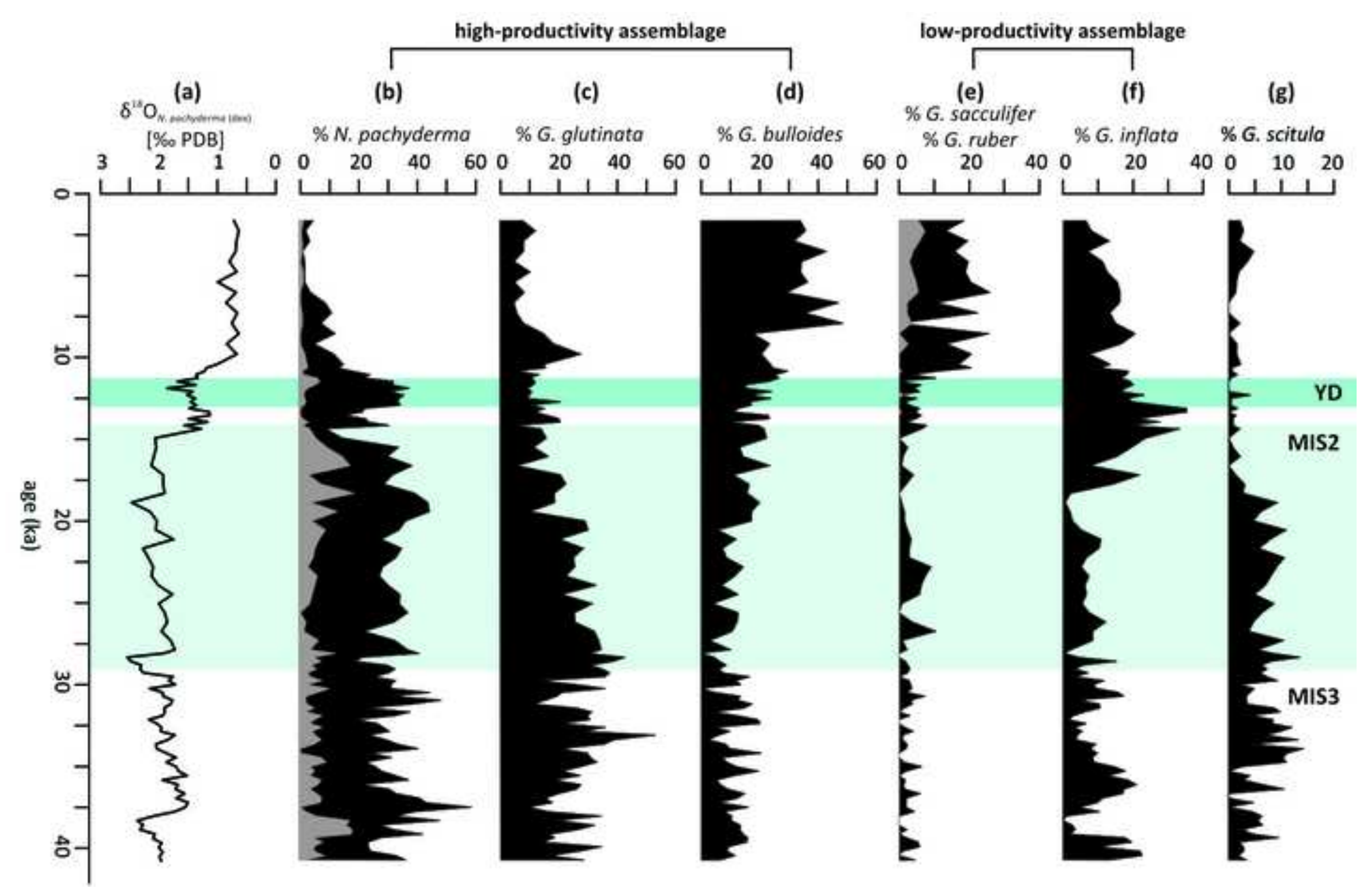


1 Table 1. Metadata of coral-bearing sediment cores collected from various sites in the Gulf of

2 Cádiz (indicated in Figure 1 as A, B, C, D). Abbreviations: Lat, latitude; Lon, longitude; Wd,

3 water depth; Rec, recovery; Mv, mud volcano; $\mathrm{Cm}$, coral mound; SM, Spanish margin; MM,

4 Moroccan margin; R, Ridge; PDE, Pen Duick Escarpment; Mo, Madrepora oculata; Lp, Lophelia

5 pertusa. Cruises: 1, RV Sonne cruise SO175; 2, RV Maria S. Merian MSM01-3; 3, RV Pelagia

6 cruise 64PE229.

\begin{tabular}{|c|c|c|c|c|c|c|c|c|c|c|}
\hline & & & Cruise & Location & Core-ID & $\begin{array}{l}\text { Lat } \\
\left({ }^{\circ} \mathrm{N}\right)\end{array}$ & $\begin{array}{l}\text { Lon } \\
\left({ }^{\circ} \mathrm{W}\right)\end{array}$ & $\begin{array}{l}\text { Wd } \\
(\mathrm{m})\end{array}$ & $\begin{array}{c}\operatorname{Rec} \\
(\mathrm{cm})\end{array}$ & Coral content \\
\hline A & Mv & SM & 1 & $\begin{array}{l}\text { Hespérides } \\
\text { Mv }\end{array}$ & $\begin{array}{l}\text { GeoB } \\
9018\end{array}$ & $36^{\circ} 10.98^{\prime}$ & $07^{\circ} 18.37^{\prime}$ & 702 & 347 & $\begin{array}{l}\text { 0-5 cm: dendrophylliids, } \\
5-347 \mathrm{~cm} \text { : solely Mo; } \\
\text { strongly altered fragments. }\end{array}$ \\
\hline B & $\mathrm{Mv}$ & SM & 1 & $\begin{array}{c}\text { Faro Mv } \\
\text { (lower flank) }\end{array}$ & $\begin{array}{l}\text { GeoB } \\
9031\end{array}$ & $36^{\circ} 05.75^{\prime}$ & $07^{\circ} 23.28^{\prime}$ & 897 & 484 & $\begin{array}{l}\text { 0-160 } \mathrm{cm} \text { : Mo-dominated; } \\
\text { strongly altered fragments. }\end{array}$ \\
\hline & $\mathrm{Mv}$ & SM & 1 & $\begin{array}{l}\text { Faro } \mathrm{Mv} \\
\text { (top) }\end{array}$ & $\begin{array}{l}\text { GeoB } \\
9032\end{array}$ & $36^{\circ} 05.55^{\prime}$ & $07^{\circ} 23.57^{\prime}$ & 843 & 220 & $\begin{array}{l}\text { 0-60 cm: Mo-dominated, } \\
60-220 \mathrm{~cm} \text { : mud breccia. }\end{array}$ \\
\hline C & $\mathrm{Cm}$ & MM & 1 & W Renard R & $\begin{array}{l}\text { GeoB } \\
9070\end{array}$ & $35^{\circ} 22.00^{\prime}$ & $06^{\circ} 51.90^{\prime}$ & 594 & $560 *$ & 0-560 cm: Mo and Lp. \\
\hline & $\mathrm{Cm}$ & MM & 2 & W Renard R & $\begin{array}{l}\text { GeoB } \\
12104\end{array}$ & $35^{\circ} 21.99^{\prime}$ & $06^{\circ} 51.90^{\prime}$ & 590 & 523 & 0-523 cm: Mo and Lp \\
\hline & $\mathrm{Cm}$ & MM & 2 & Renard R & $\begin{array}{l}\text { GeoB } \\
12102\end{array}$ & $35^{\circ} 21.11^{\prime}$ & $06^{\circ} 50.96^{\prime}$ & 585 & 518 & $\begin{array}{l}\text { 0-518 cm: Mo, Lp, and } \\
\text { dendrophylliids. }\end{array}$ \\
\hline & $\mathrm{Cm}$ & MM & 2 & Renard R & $\begin{array}{c}\text { GeoB } \\
12103\end{array}$ & $35^{\circ} 21.18^{\prime}$ & $06^{\circ} 50.90^{\prime}$ & 591 & 568 & 0-568 cm: Mo and Lp. \\
\hline & $\mathrm{Cm}$ & MM & 2 & PDE & $\begin{array}{l}\text { GeoB } \\
12101\end{array}$ & $35^{\circ} 18.88^{\prime}$ & $06^{\circ} 48.08^{\prime}$ & 545 & 468 & $\begin{array}{l}\text { 0-468 cm: Mo, Lp, and } \\
\text { dendrophylliids. }\end{array}$ \\
\hline & $\mathrm{Cm}$ & MM & 3 & PDE & M2004-02 & $35^{\circ} 17.68^{\prime}$ & $06^{\circ} 47.25^{\prime}$ & 523 & 861 & $\begin{array}{l}\text { 0-861 cm: Mo, Lp, and } \\
\text { dendrophylliids. }\end{array}$ \\
\hline D & $\mathrm{Cm}$ & MM & 2 & $\begin{array}{c}\mathrm{N} \text { of } \\
\text { Meknes Mv }\end{array}$ & $\begin{array}{c}\text { GeoB } \\
12106\end{array}$ & $34^{\circ} 59.49^{\prime}$ & $07^{\circ} 04.56^{\prime}$ & 758 & 303 & 30-303 cm: Mo and Lp. \\
\hline
\end{tabular}

$7 *$ the uppermost $40 \mathrm{~cm}$ of core GeoB 9070 were disturbed due to coring operation, thus the undisturbed core 8 depth ranges from 40 to $600 \mathrm{~cm}$ 
Table 2. Ages, isotope concentrations and ratios (n.a., not available).

\begin{tabular}{|c|c|c|c|c|c|c|c|c|c|c|c|c|c|c|}
\hline $\mathbf{N}^{\circ}$ & Sample ID & $\begin{array}{c}\text { Depth } \\
(\mathrm{cm})\end{array}$ & Coral & Labcode & $\begin{array}{l}\text { Age } \\
\text { (ka) }\end{array}$ & $\begin{array}{c} \pm \\
(\mathrm{ka})\end{array}$ & $\begin{array}{c}{ }^{\mathbf{2 3 8}} \mathbf{U} \\
(\mathrm{ppm})\end{array}$ & $\begin{array}{c} \pm \\
(\mathrm{ppm})\end{array}$ & $\begin{array}{l}{ }^{232} \mathrm{Th} \\
\text { (ppb) }\end{array}$ & $\begin{array}{c} \pm \\
(\mathrm{ppb})\end{array}$ & $\begin{array}{c}\delta^{234} \mathrm{U}(\mathrm{M}) \\
(\% \circ)\end{array}$ & $\begin{array}{c} \pm \\
(\%)\end{array}$ & $\begin{array}{c}\delta^{234} U(0) \\
(\%)\end{array}$ & $\begin{array}{c} \pm \\
(\% \circ)\end{array}$ \\
\hline & 1 & 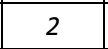 & 3 & 4 & 5 & & 6 & & 7 & & 8 & & 9 & \\
\hline 01 & GeoB 9018 & & $M$ & n.a. & 14.65 & 0.09 & 4.020 & 0.004 & 21.019 & 0.052 & 149.8 & 1.9 & 156.1 & 2.0 \\
\hline 02 & GeoB 9018 & & & n.a. & 294.00 & 7.00 & 4.329 & 0.004 & 3.021 & 0.006 & 73.1 & 1.4 & 167.7 & 3.3 \\
\hline 03 & GeoB 9018 & 272 & Mo & n.a. & 283.80 & 8.50 & 4.005 & 0.004 & 23.536 & 0.064 & 61.9 & 1.5 & 138.0 & 3.3 \\
\hline 04 & eоB 9031 & 1 & & & .92 & 0.12 & 4.956 & 0.005 & 21.400 & 0.055 & 139.9 & 1.8 & 148.5 & 1.9 \\
\hline 05 & GeoB 9031 & 93 & Mo & n.a. & 37.25 & 0.23 & 5.263 & 0.007 & 4.796 & 0.009 & 132.8 & 2.3 & 147.5 & 2.5 \\
\hline 06 & GeoB 9031 & 150 & Mo & n.a. & 45.94 & 0.33 & 4.338 & 0.004 & 8.875 & 0.016 & 120.6 & 1.4 & 137.4 & 1.6 \\
\hline 07 & GeoB 9032 & 20 & $M$ & n.a. & 17.15 & 0.15 & 4.447 & 0.005 & 62.092 & 0.192 & 140.6 & 1.6 & 147.6 & 1.7 \\
\hline 08 & GeoB 9032 & 47 & 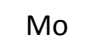 & n.a. & 1.17 & 0.25 & 4.512 & 0.005 & 25.841 & 0.070 & 130.3 & 1.8 & 146.4 & 2.0 \\
\hline 09 & 70 & & & n.a. & & 0.12 & 4.622 & 0.003 & 4.428 & 0.010 & 137.9 & 1.1 & 147.3 & 1.2 \\
\hline 10 & GeoB 9070 & 298 & Mo & n.a. & 3.68 & 0.28 & 3.552 & 0.003 & 51.216 & 0.079 & 129.6 & 1.8 & 146.6 & 2.0 \\
\hline 11 & GeoB 9070 & 520 & Mo & n.a. & 166.00 & 2.40 & 3.968 & 0.004 & 15.089 & 0.033 & 78.7 & 1.7 & 125.9 & 2.7 \\
\hline 12 & GeoB 12101 & 57 & Mo & if-1525 & not date & eable & 3.085 & 0.004 & 0.351 & 0.002 & 59.5 & 3.2 & I & I \\
\hline 13 & GeoB 12101 & 146 & Lp & Gif-1389 & not date & eable & 3.214 & 0.004 & 0.920 & 0.003 & 47.4 & 3.0 & / & / \\
\hline 14 & GeoB 12101 & 451 & Mo & if-1527 & 430.76 & 56.55 & 2.589 & 0.002 & 8.092 & & 48.9 & 3.3 & 165.2 & 3.3 \\
\hline 15 & oB 12102 & 28 & & & 57.96 & 0.74 & 4.390 & 0.005 & 0.316 & & 119.5 & 2.7 & 140.8 & 2.7 \\
\hline 16 & oов 12102 & 166 & & $11-15<0$ & 118.16 & 1.10 & 4.220 & 0.003 & 1.075 & 0.003 & 103.0 & 1.9 & 143.8 & 1.9 \\
\hline 17 & еов 12102 & 238 & & $f-1390$ & 152.27 & 5.12 & 3.035 & 0.003 & 0.306 & 0.003 & 112.1 & 2.9 & 172.4 & 2.9 \\
\hline 18 & oо 12102 & 376 & Mo & $f-1388$ & 151.56 & 3.37 & 3.614 & 0.003 & 0.491 & 0.002 & 90.7 & 3.0 & 139.2 & 3.0 \\
\hline 19 & еоB 12102 & 493 & Mo & if-1386 & 164.02 & 2.01 & 3.194 & 0.003 & 0.495 & 0.002 & 99.5 & 1.8 & 158.3 & 1.8 \\
\hline 20 & eoB 12103 & 34 & 1 & if-1530 & 22.88 & 0.38 & 3.881 & 0.004 & 0.636 & 0.003 & 131.0 & 2.0 & 139.8 & 2.0 \\
\hline 21 & GeoB 12103 & 88 & Lp & if-1392 & 25.72 & 0.39 & 4.462 & 0.006 & 3.873 & 0.010 & 128.7 & 2.9 & 138.4 & 2.9 \\
\hline 22 & GeoB 12103 & 200 & Mo & if 1521 & 29.98 & 1.26 & 3.610 & 0.004 & 2.644 & 0.011 & 129.4 & 3.3 & 140.9 & 3.3 \\
\hline 23 & jeoB 12103 & 317 & Mo & Gif-1532 & 30.43 & 0.96 & 3.828 & 0.004 & 0.192 & 0.003 & 126.9 & 2.2 & 138.3 & 2.2 \\
\hline 24 & еов 12103 & 444 & & & 49.85 & 0.80 & 3.693 & 0.005 & 19.205 & 0.071 & 121.1 & 2.4 & 139.4 & 2.4 \\
\hline 25 & 00121 & 8 & & & 23.57 & 0.18 & 4.435 & & & & 126.3 & 1.7 & 135.0 & 1.7 \\
\hline 26 & ooB 12104 & 73 & & 34 & 1.20 & 15.74 & 3.658 & 0.003 & 61 & D12 & 6 & 2.2 & 168.3 & 2.2 \\
\hline 27 & eoB 12104 & 491 & Mo & if-1535 & 342.29 & 25.38 & 3.492 & 0.004 & 2.003 & 0.008 & 71.1 & 2.6 & 187.1 & 2.6 \\
\hline 28 & GeoB 12106 & 117 & Mo & if-1391 & 295.86 & 23.27 & 3.421 & 0.004 & 3.421 & 0.004 & 65.9 & 2.8 & 152.0 & 2.8 \\
\hline 29 & $1012004-62$ & 49 & Mo & & 9.15 & 0.71 & 3.512 & 0.011 & & & 149.3 & 3.0 & 153.2 & 3.0 \\
\hline 30 & & & & & & 0.54 & 3.943 & 0.007 & & & 138.8 & 2.5 & 146.6 & 2.5 \\
\hline 31 & M2004-02 & & & & 19.87 & 0.52 & 3.284 & 0.010 & & & 136.0 & 3.9 & 143.9 & 3.9 \\
\hline 32 & M2004-02 & 141 & & דכטגו & 21.37 & 0.42 & 3.862 & 0.007 & 4.666 & 0.013 & 136.5 & 2.3 & 145.0 & 2.3 \\
\hline 33 & M2004-02 & 147 & & Gif-1635 & 22.75 & 0.26 & 4.016 & 0.006 & 2.209 & 0.006 & 133.0 & 2.9 & 141.8 & 2.9 \\
\hline 34 & M2004-02 & 176 & & Gif-1636 & 24.03 & 0.26 & 3.921 & 0.008 & 11.534 & 0.031 & 131.4 & 3.3 & 140.6 & 3.3 \\
\hline 35 & M2004-02 & 247 & & Gif-1637 & 34.90 & 0.43 & 3.099 & 0.004 & 0.310 & 0.001 & 130.3 & 2.5 & 143.8 & 2.5 \\
\hline 36 & M2004-02 & 273 & Mo & if- 1638 & 36.27 & 0.43 & 3.804 & 0.008 & 3.049 & 0.008 & 124.5 & 1.6 & 138.0 & 1.6 \\
\hline 37 & M2004-02 & 313 & $\mathrm{~L}$ & Gif-1639 & 142.08 & 1.92 & 4.068 & 0.010 & 2.908 & 0.009 & 96.6 & 2.3 & 144.4 & 2.4 \\
\hline 38 & M2004-02 & 343 & & & 175.01 & 2.79 & 3.846 & 0.005 & 14.820 & 0.026 & 85.3 & 2.5 & 139.9 & 2.5 \\
\hline 39 & M2004-02 & 363 & Mo & & 242.07 & 8.35 & 3.174 & 0.008 & 0.506 & 0.003 & 85.4 & 2.7 & 169.3 & 2.7 \\
\hline 40 & M2004-02 & 403 & & if-1642 & 262.80 & 7.46 & 3.126 & 0.007 & 3.116 & 0.007 & 74.2 & 2.9 & 155.9 & 2.9 \\
\hline
\end{tabular}

NOTE: Column 1: Sample label. Column 2: Depth in core. Column 3: Reef-forming scleractinian cold-water coral species, Lp Lophelia pertusa, Mo Madrepora oculata. Column 4: Labcode (not available for datings conducted at IFM-GEOMAR, $\mathrm{N}^{\circ} 1$ 11). Column 5: Calculated coral ages. Column 6: ${ }^{238} \mathrm{U}$ concentration. Column 7: ${ }^{232} \mathrm{Th}$ concentration. Column 8: Measured ${ }^{234} \mathrm{U} /{ }^{238} \mathrm{U}$ activity ratios $\left(\delta^{234} \mathrm{U}(\mathrm{M})\right)$ are presented as deviation per mil (\%o) from the equilibrium value. Column 9: Decay corrected ${ }^{234} \mathrm{U} /{ }^{238} \mathrm{U}$ activity ratios $\left(\delta^{234} \mathrm{U}(0)\right)$ are calculated from the given ages and with $\lambda_{234 \mathrm{U}}: 2.8263 \times 10^{-6} \mathrm{yr}^{-1}$. Note that ages are strictly reliable having values between $146.6 \%$ and $149.6 \%$ (modern seawater), reliable with values of $149 \pm 10 \%$, unreliable with values $>149 \pm 10 \%$ (see also Stirling et al., 1998; Robinson et al., 2004; Esat and Yokoyama, 2006). 
19 Table 3. AMS ${ }^{14} \mathrm{C}$ dates determined on multi-species samples of planktonic foraminifera

20 from sediment core GeoB 9064. The AMS ${ }^{14} \mathrm{C}$ ages were corrected for ${ }^{13} \mathrm{C}$ and a mean ocean

21 reservoir age of 400 years, and were converted to calendar years using the CALPAL 2007

22 Hulu software. Estimated sedimentation rates for core GeoB 9064 are supplemented.

\begin{tabular}{|c|c|c|c|c|c|c|}
\hline \multirow{3}{*}{$\begin{array}{l}\text { Core } \\
\text { depth } \\
(\mathrm{cm})\end{array}$} & \multirow{3}{*}{ Labcode } & \multicolumn{2}{|c|}{ Conventional age } & \multicolumn{2}{|c|}{ CALPAL age } & \multirow{3}{*}{$\begin{array}{l}\text { Sedimentation } \\
\text { rate } \\
\left(\mathrm{cm} \mathrm{kyr}^{-1}\right)\end{array}$} \\
\hline & & ${ }^{14} \mathrm{C}$ age & \pm error & $1 \sigma(68 \%)$ & \pm error & \\
\hline & & \multicolumn{2}{|l|}{ (years) } & \multicolumn{2}{|c|}{ (calendar years B.P., P.=AD 1950) } & \\
\hline \multicolumn{7}{|c|}{ GeoB 9064} \\
\hline 4 & Poz-20282 & 2095 & 30 & 1630 & 50 & - \\
\hline 74 & KIA-10065 & 9665 & 60 & 10430 & 100 & 7.95 \\
\hline 169 & KIA-13060 & 12660 & 80 & 14370 & 240 & 24.11 \\
\hline 289 & KIA-23840 & 23440 & 180 & 27860 & 190 & 8.90 \\
\hline 399 & KIA-29420 & 29020 & 320 & 33090 & 420 & 21.03 \\
\hline 524 & KIA-35660 & 35260 & 630 & 39960 & 960 & 18.20 \\
\hline
\end{tabular}

23 